\title{
THE LATEST GEODYNAMICS IN CENTRAL ASIA: PRIMARY AND SECONDARY MANTLE MELTING ANOMALIES IN THE CONTEXT OF OROGENESIS, RIFTING, AND LITHOSPHERIC PLATE MOTIONS AND INTERACTIONS
}

\author{
I. S. Chuvashova1, 2, S. V. Rasskazov ${ }^{1,2}$, Yi-min Sun ${ }^{3}$ \\ ${ }^{1}$ Institute of the Earth's Crust, Siberian Branch of RAS, Irkutsk, Russia \\ 2 Irkutsk State University, Irkutsk, Russia \\ ${ }^{3}$ Institute of Volcanoes and Mineral Springs, Heilongjiang Academy of Science, \\ Wudalianchi, Heilongjiang, China
}

\begin{abstract}
A comprehensive model for deep dynamics in Asia has been developed from the data on the evolution of melting anomalies in the context of lithospheric plate motions, interactions, orogeny, and rifting. The key components of our model are the primary (transition layer) and secondary (upper mantle) melting anomalies (Gobi, Baikal, and North Transbaikalia; and Hangay, Sayan, and Vitim, respectively). It is inferred that the primary melting anomalies originated at the beginning of the latest geodynamic stage (ca. $90 \mathrm{Ma}$ ) as a result of the transition layer distortion by lower mantle flows. Such primary anomalies were caused by avalanche collapses of the slab material that had been stagnated under the closed fragments of the Solonker, Ural-Mongolian paleooceans and the Mongol-Okhotsk Bay of Paleopacific. The secondary melting anomalies occurred due to the Early-Middle Miocene structural reorganization in the Pacific-Asian and Indo-Asian interaction zones. The primary melting anomalies governed the spatial distribution of forces and processes of the latest geodynamic stage. The secondary melting anomalies resulted from the lithospheric motions relative to the primary anomalies and provided for the development of orogeny and rifting. The BaikalMongolian corridor of asthenospheric flows was limited by the lateral zones of convergent interactions between India and Asia in the southwest, and North America and Asia in the northeast. In these lateral zones, Late Phanerozoic paleoslabs and ascending mantle fluxes were revealed in the transition layer, as well as in the upper mantle, without any destruction by the asthenospheric flows.
\end{abstract}

Key words: volcanism; orogen; rift; Cretaceous; Cenozoic; latest geodynamic stage; Asia; asthenosphere; lithosphere

\section{RESEARCH ARTICLE}

Recommended by V.A. Sankov
Received: April 5, 2016

Revised: December 14, 2016

Accepted: January 25, 2017

For citation: Chuvashova I.S., Rasskazov S.V., Yi-min Sun, 2017. The latest geodynamics in Central Asia: primary and secondary mantle melting anomalies in the context of orogenesis, rifting, and lithospheric plate motions and interactions. Geodynamics \& Tectonophysics 8 (1), 45-80. doi:10.5800/GT-2017-8-1-0232.

Для цитирования: Чувашова И.С., Рассказов С.В., Йи-минь Сунь. Новейшая геодинамика Центральной Азии: первичные и вторичные мантийные расплавные аномалии в контексте орогенеза, рифтогенеза и движения-взаимодействия литосферных плит // Геодинамика и тектонофизика. 2017. T. 8. № 1. C. 45-80. doi:10.5800/GT-2017-8-1-0232. 


\title{
НОВЕЙШАЯ ГЕОДИНАМИКА ЦЕНТРАЛЬНОЙ АЗИИ: ПЕРВИЧНЫЕ И ВТОРИЧНЫЕ МАНТИЙНЫЕ РАСПЛАВНЫЕ АНОМАЛИИ В КОНТЕКСТЕ ОРОГЕНЕЗА, РИФТОГЕНЕЗА И ДВИЖЕНИЯ-ВЗАИМОДЕЙСТВИЯ ЛИТОСФЕРНЫХ ПЛИТ
}

\author{
И. С. Чувашова ${ }^{1,2}$, С. В. Рассказов ${ }^{1,2}$, Йи-минь Сунь ${ }^{3}$ \\ ${ }^{1}$ Институт земной коры СО РАН, Иркутск, Россия \\ ${ }^{2}$ Иркутский государственный университет, Иркутск, Россия \\ ${ }^{3}$ Институт вулканов и минеральных источников Хэйлунцзянской академии наук, \\ Удаляньчи, Хэйлунцзян, Китай
}

\begin{abstract}
Аннотация: По данным об эволюции расплавных аномалий в контексте орогенеза, рифтогенеза, движения и взаимодействия литосферных плит развита обобщающая модель глубинной динамики Азии, в которой важнейшую роль играли первичные Гобийская, Байкальская и Северо-Забайкальская расплавные аномалии переходного слоя и вторичные Хангайская, Саянская и Северо-Байкальская расплавные аномалии верхней мантии. Предполагается, что первичные расплавные аномалии формировались в начале новейшего геодинамического этапа (около 90 млн лет назад) в результате нарушения переходного слоя нижнемантийными потоками из-за лавинного обрушения слэбового материала, который стагнировал под закрывшимися фрагментами Солонкерского, Урало-Монгольского палеоокеанов и Монголо-Охотского залива Палеопацифика, а вторичные получили развитие в связи с процессами раннесреднемиоценовой структурной перестройки в зонах Тихоокеанско-Азиатского и Индо-Азиатского взаимодействия. Первичные расплавные аномалии служили в качестве главного фактора пространственного распределения усилий и процессов новейшего геодинамического этапа, а вторичные явились следствием движения литосферы относительно первичных аномалий и способствовали развитию орогенеза и рифтогенеза. Японско-Байкальский геодинамический коридор сдерживался латеральными зонами конвергентного взаимодействия Индостана и Азии на юго-западе и Северной Америки и Азии на северо-востоке. В латеральных зонах сдерживания позднефанерозойские палеослэбы и восходящие мантийные потоки были зафиксированы в переходном слое и верхней мантии без разрушения астеносферными потоками.
\end{abstract}

Ключевые слова: вулканизм; ороген; рифт; мел; кайнозой; новейший геодинамический этап; Азия; астеносфера; литосфера

\section{1. ВВЕДЕНИЕ}

В концепции глобальной тектоники предполагается, что литосферные плиты перемещаются благодаря эффекту волочения, обусловленному 1) мантийным потоком, действующим на основание литосферы, и 2) граничными силами, действующими вдоль краев плит. Поток в астеносфере рассматривается в качестве производного движения литосферы. Эффект волочения литосферы и градиент давления в астеносфере при ее смещении либо субдуцирующим слэбом, либо возвратным течением мантии в сторону срединного океанического хребта может вызвать противопоток [Forsyth, Uyeda, 1975; Smith, Lewis, 2003; Turcotte, Schubert, 2014]. Kaким образом инициируется субдукция - часто остается неясным (см. например [Niu et al., 2003; Stern, 2004]). Проблема источника (или источников) сил, приводящих в движение континентальную литосферу, остается слабоизученной.
До второй половины 1990-х годов модели плитной тектоники строились относительно неподвижной Антарктиды на основе данных о строении дна океанов, прогрессий горячих пятен и механизмов очагов землетрясений на межплитных границах. Евразия считалась неподвижной или смещающейся с небольшой скоростью. Предполагались разные направления движения [Minister, Jordan, 1978; Engebretson et al., 1984, 1985; DeMets et al., 1990, 1994; Wuming et al., 1992]. Смещение вулканизма в Центральной Европе от Нижней Силезии (Польша) до Эйфеля (Западная Германия) на протяжении последних 35 млн лет рассматривалось как следствие движения плиты на восток со скоростью 2.3 см ×год ${ }^{-1}$ [Duncan et al., 1972], а смещение вулканизма Восточного Саяна в том же направлении в последние 20 млн лет, выявленное одним из авторов настоящей работы, - как следствие ее движения с меньшей локальной скоростью $\left(0.8\right.$ см.год $\left.{ }^{-1}\right)$. Предполагалось современное движение восточной 
части Евразии к северо-востоку со скоростью 0.4 см-год ${ }^{-1}$ [Plate-Tectonic map..., 1984] либо к югу со скоростью 1.0 см·год ${ }^{-1}$ [Simkin et al., 1989]. Полученные данные GPS-геодезии показали, однако, современное смещение восточной части Евразии в направлении на восток-юго-восток с высокой скоростью (около 3 см·год-1). Такое значение скорости было впервые зарегистрировано Иркутской станцией GPS, расположенной на юго-восточной окраине Стабильной Азии [Rothacher et al., 1996].

В конце XX - начале XXI в. мантийная геодинамика азиатской части континента служила предметом дискуссии на основе: 1) анализа структурного рисунка четвертичных тектонических деформаций в Азии, предполагаемых движений блоков в кайнозое, в том числе на основе механизмов очагов землетрясений и данных GPS-геодезии [Molnar, Tapponnier, 1975; Tapponnier et al., 1982; Jolivet et al., 1994; England, Molnar, 1997; Fournier et al., 2004; Molnar, 2005; Sankov et al., 2011], 2) констатации пространственного или пространственно-временного распределения вулканизма позднего мезозоя и кайнозоя без конкретизации элементов строения переходного слоя и верхней мантии [Yarmolyuk et al., 2007], 3) геофизических исследований современной структуры верхней мантии без учета вулканической эволюции [Zorin et al., 2003, 2006]; 4) peгистрации низкоскоростных мантийных аномалий под полями четвертичного вулканизма [Lei, Zhao, 2005; Zhao, 2009; Wei et al., 2012] и 5) совместного анализа данных о пространственно-временном распределении новейшего вулканизма и низкоскоростных мантийных аномалий [Rasskazov et al., 2003; Rasskazov, Chuvashova, 2016].

В последней работе было дано определение новейшего геодинамического этапа, в течение которого Азия вовлекалась в восток-юго-восточное движение со встречной субдукцией плит Тихого океана. Был обозначен подход к анализу глубинной динамики Байкало-Монгольского региона, в основу которого было положено определение природы активизации литосферы Внутренней Азии вследствие складирования материала Солонкерского, Урало-Монгольского палеоокеанов и МонголоОхотского залива Палеопацифика в переходном слое мантии и его обрушения в нижнюю мантию. В Байкало-Монгольском регионе были выделены Гобийская, Байкальская ${ }^{1}$ и Северо-Забайкальская расплавные аномалии переходного слоя и пространственно-сопряженные с этими аномалиями верхнемантийные расплавные структуры. Гипотеза новейшей динамики расплавных мантийных анома-

\footnotetext{
1 Мел-палеогеновые вулканические породы и центр низкоскоростной аномалии переходного слоя этой структуры фактически находятся в Западном Забайкалье, поэтому она характеризуется в настоящей работе как Западно-Забайкальская.
}

лий Азии под движущейся литосферой получает в настоящей работе развитие и дополнительную аргументацию. Наряду с переходом от предшествующего раннесреднефанерозойского этапа к позднефанерозойскому (послесреднемеловому) на ее территории в связи со структурными перестройками на азиатско-тихоокеанской границе, определяется характер развития процессов в области ИндоАзиатского взаимодействия. Рассматриваются соотношения между низкоскоростными мантийными аномалиями, вулканизмом, фрагментами швов закрывшихся фанерозойских палеоокеанов и современными межплитными границами. На динамику подлитосферных потоков Азии вводятся латеральные ограничения в зонах ее конвергенции с Индостаном и Северной Америкой.

\section{2. ГЕОДИНАМИЧЕСКИЕ ГИПОТЕЗЫ}

\section{1. ПОДЛИТОСФЕРНЫЕ РАСПЛАВНЫЕ АНОМАЛИИ}

В геодинамике как науке, оформившейся в 1970-х годах, определяющее место, наряду с концепцией литосферных плит, занимает концепция мантийных расплавных аномалий, явившаяся результатом продолжительной дискуссии о происхождении внутриплитного мантийного магматизма [Morgan, 1971; Hofmann, 1997; Anderson, 2007; Maruyama et al., 2007; Foulger, 2010; Karato, 2012; Rasskazov, Chuvashova, 2016]. Имеющиеся фактические данные свидетельствуют о том, что подлитосферным источником магм может служить: 1) плюм, начинающийся от нижнего термального граничного слоя мантии (т.е. границы ядро-мантия), 2) расплавная аномалия переходного слоя 410-660 км, 3) расплавная аномалия домена, расположенного выше переходного слоя (на глубинах 200-410 км), и 4) расплавная аномалия домена, расположенного под литосферой (на глубинах 50200 км) (рис. 1). Чем глубже находится магмогенерирующая область, тем выше температура (а следовательно, и энергетический потенциал) материала, который может адиабатически подняться в малоглубинную часть расплавной аномалии и излиться на земную поверхность.

На основе геохимических отличий базальтов срединных океанических хребтов (MORB) и базальтов океанических островов (OIB) изначально постулировалось, что источник последних находится исключительно в глубокой части мантии [Morgan, 1971]. Такой источник, отнесенный к нижней термальной границе мантийной конвектирующей системы, рассматривался в качестве плюмового [Anderson, 1995]. Плюмовая гипотеза подтвердилась сейсмической томографией высокого разре- 
ПОДЛИТОСФЕРНЫЕ ИСТОЧНИКИ ВУЛКАНИЗМА

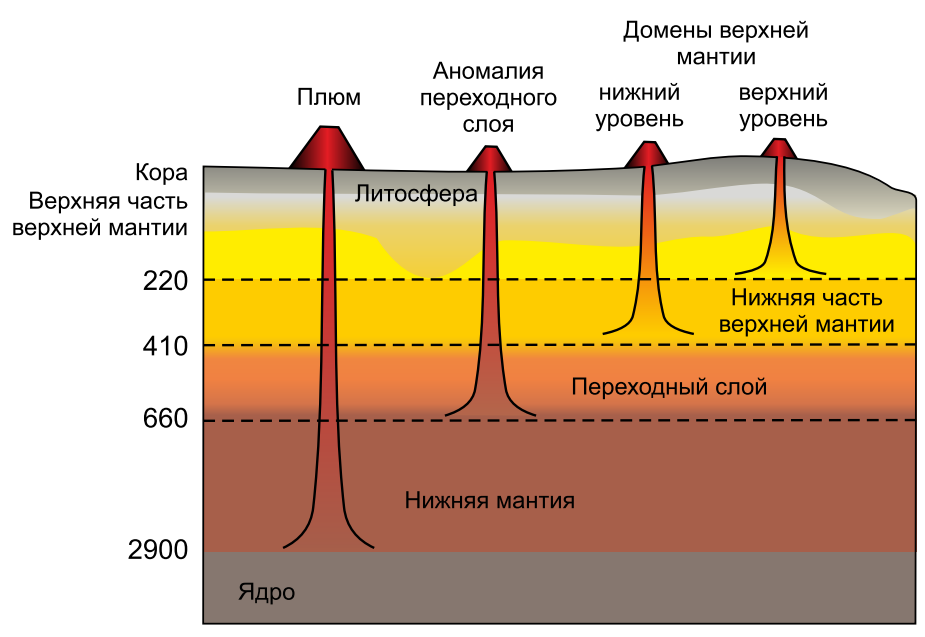

Глубина (км)

Рис. 1. Систематика подлитосферных мантийных расплавных аномалий на континентах.

Fig. 1. Systematics of sub-lithospheric mantle melting anomalies in continents.

шения в мантии под океаническими островами Гавайи, Таити и другими [Montelli et al., 2004; Zhao, 2009]. Короткий период активности крупных магматических провинций объяснялся поднятием нижнемантийных капель. Теоретически допускалась смена режима плавления в такой капле более локальным плавлением в нижнемантийном плюме. Такие переходы ограничены четырьмя примерами (Плато Декан - Реюнион, Плато Онтонг Джава Луизвиль, Парана/Этендека - Тристан, Колумбия Ривер - Йеллоустоун), каждый из которых имеет отклонения, противоречащие принятой модели [Foulger, 2010].

Иной характер геодинамики предполагался в связи с аккумуляцией субдуцируемого океанического материала, стагнирующего в переходном мантийном слое и лавинообразно погружающегося в нижнюю мантию с возникновением обратного потока горячего материала (рис. 2).

В случае восхождения горячего потока из нижней мантии в верхнюю через переходный слой, последний утоняется в верхней и нижней части, как это следует из противоположного наклона Клапейрона [Ito, Takahashi, 1989; Anderson, 2007; Maruyama et al., 2007]. Утонение переходного слоя в целом подтверждается антикорреляцией его верхней и нижней границы [Shen et al., 1998; Li et al., 2000, 2003; Owens et al., 2000; Hooft et al., 2003], хотя в некоторых регионах (например, в западной части Северной Америки) границы 410 и 660 км антикоррелируются друг с другом не всегда [Houser et al., 2008].
В последние годы обсуждается гипотеза плавления, в которой предполагается особая роль переходной зоны с содержанием $\mathrm{H}_{2} \mathrm{O}$ более $\sim 0.05$ \%. Постулируется зарождение выплавок при апвеллинге материала с глубины 410 км [Hirschmann et al., 2009; Karato, 2012]. Такой материал должен находиться в частично расплавленном состоянии, пока не достигнет основания литосферы. Предполагается общий характер нисходящего движения материала, реализующегося в зоне субдукции, и медленное распределение апвеллинговых течений, охватывающих большую часть мантии. Согласно этой гипотезе, большая часть верхнемантийного материала должна представлять собой остаток малой степени частичного плавления на разделе 410 км. Однородная, умеренно обедненная астеносфера рассматривается как остаточный продукт такого плавления [Bercovici, Karato, 2003; Karato, 2012].

Наконец, под океанической литосферой выделяется низковязкостный слой толщиной около 100 км, для которого характерны низкие скорости (особенно S-волн) и сейсмическая анизотропия. Поскольку низкоскоростные аномалии протягиваются под срединными хребтами не глубже 100 км и эти аномалии коррелируются со скоростями спрединга, считается, что в них действует механизм «пассивного» поднятия [Zhang, Tanimoto, 1992; Anderson et al., 1992]. В теоретических построениях флюидной механики важная роль отводится низкоскоростному слою подлитосферной мантии толщиной до 200 км [Turcotte, Schubert, 2014].

Верхнемантийные источники позднекайнозойского вулканизма Азии связывались с низкоскоростными аномалиями, объединяющимися в малоглубинный (до 200 км) Саяно-Хангайский домен и более глубинный (до переходного слоя) Забайкальский, происхождение которых объяснялось, соответственно, коллизионным воздействием на Азию Индостана и субдукцией под Азию плит КулаИзанаги и Тихоокеанской [Rasskazov et al., 2003].

\section{2. ЛИТОСФЕРНО-ПОДЛИТОСФЕРНЫЕ РАСПЛАВНЫЕ АНОМАЛИИ}

Источники мантийных расплавных аномалий могут находиться не только под литосферой, но и в литосфере. В работах 1970-1980-х годов были предложены варианты классификаций континентальных рифтовых зон - структур, формирующихся в результате растяжения литосферы. В одних классификациях [Milanovsky, 1976; Logachev, 1977] учитывался объем рифтогенного вулканизма и рифтовые зоны делились на сводово-вулканические и щелевые (слабовулканические). В других определялся механизм растяжения литосферы: «активный» или «пассивный» [Sengör, Burke, 1978; Turcotte, Emerman, 1983]. В гипотезе «пассивного» 


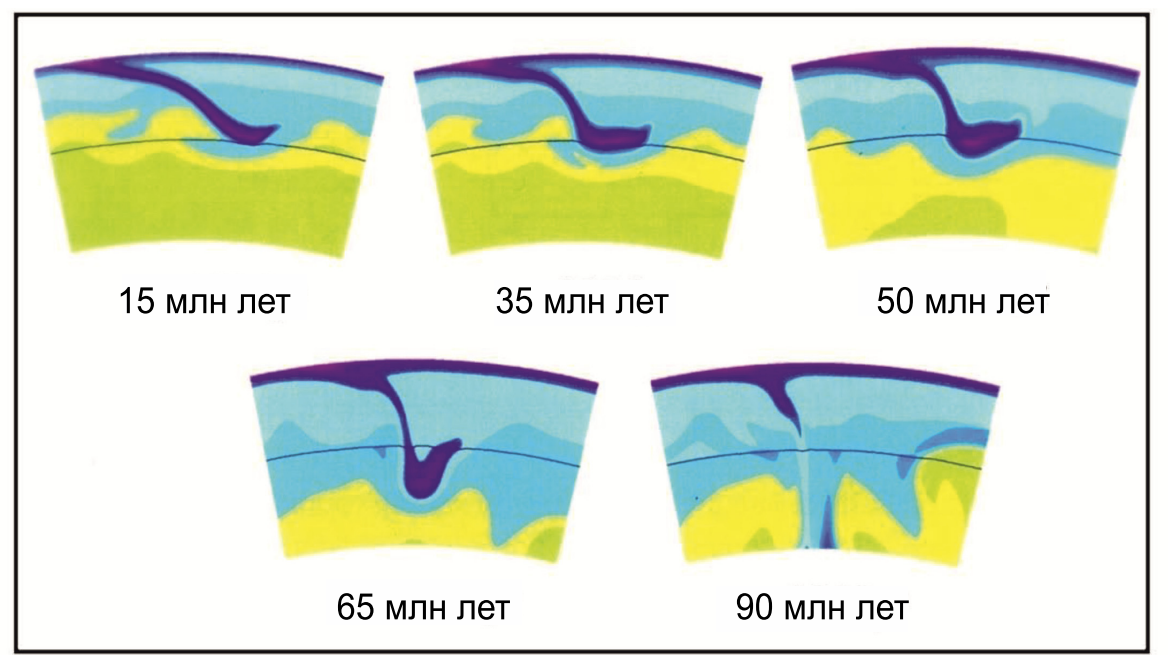

Рис. 2. Результаты компьютерного моделирования погружения слэба через границу 660 км [Mitrovica et al., 2000]. Подобное компьютерное моделирование проводилось в работах [Yoshioka, Sanshadokoro, 2002; и др.].

Fig. 2. The results of computer simulation of a slab dive across the boundary at $660 \mathrm{~km}$ [Mitrovica et al., 2000]. Similar computer simulations were performed by Yoshioka and Sanshadokoro [2002] and others.

рифтогенеза предполагалось начало рифтового процесса сверху - с раскалывания коры и мантийной части литосферы под влиянием внутриплитного растяжения, в концепции «активного» рифтогенеза его первопричиной считался подъем мантийного материала. В модели «пассивного» механизма главным аргументом служило существование протяженных и нередко длительно развивающихся рифтовых систем, часто ориентированных параллельно или перпендикулярно границам литосферных плит. Суть оригинальных моделей «активных» и «пассивных» процессов представлена на рис. 3. В модели «активного» рифтогенеза поднятие астеносферного материала приводит к утонению литосферы под осью рифта, в модели «пассивного» рифтогенеза предполагается первичное растяжение коры и, как следствие, поднятие материала астеносферы по узкому каналу мантийной литосферы и его растекание под корой с ее утонением. В систематике [Şengör, Natal'in, 2001] все рифты Азии отнесены к «пассивным», включая Байкальскую рифтовую зону.

В более поздних работах приведены данные о смене источников вулканизма Азии, свидетельствующие о его развитии не только в структурах растяжения коры (рифтов), но и в структурах, сформировавшихся в условиях преобладающего сжатия (орогенах), эволюционировавших с деламинацией утолщенного литосферного киля. Анализ соотношений литосферного и подлитосферного материала в продуктах вулканизма новейшего геодинамического этапа Азии показал, что понимание глубинных процессов как «пассивных» или «актив- ных» не более чем априорная оценка ситуации. В суждениях такого рода, прежде всего, важно определить характер соотношений литосферных и подлитосферных компонентов вулканических пород [Chuvashova et al., 2016]. «Активное» термальное утонение литосферы Азии зависит от флюидонасыщенности и теплосодержания глубинных магмогенерирующих процессов, которые оказываются достаточными или недостаточными для вовлечения в плавление подошвы литосферы.

В качестве литосферно-подлитосферных мы рассматриваем расплавные аномалии: 1) нижней части литосферы, претерпевшей термальное утонение в результате адиабатического поднятия горячего мантийного материала с развитием «активного» рифтогенеза (рис. $3, a), 2$ ) деламинированной корневой части формирующегося орогена, 3) растягивающейся малоглубинной (преимущественно коровой) части литосферы без утонения ее мантийной части с развитием «пассивного» рифтогенеза (рис. 3 , б) и, наконец, 4) вулканических извержений без признаков эффективного растяжения верхней части коры (рис. 4).

\section{3. ПЕРВИЧНЫЕ И ВТОРИЧНЫЕ РАСПЛАВНЫЕ АНОМАЛИИ}

Расплавные аномалии плюмов и переходного слоя рассматриваются как первичные, поскольку энергетически связаны с исходными процессами, эпизодически порождающими конвективную нестабильность нижней мантии, соответственно, на границе с ядром и переходным слоем. Расплавные колонны этого типа могут отклоняться в 


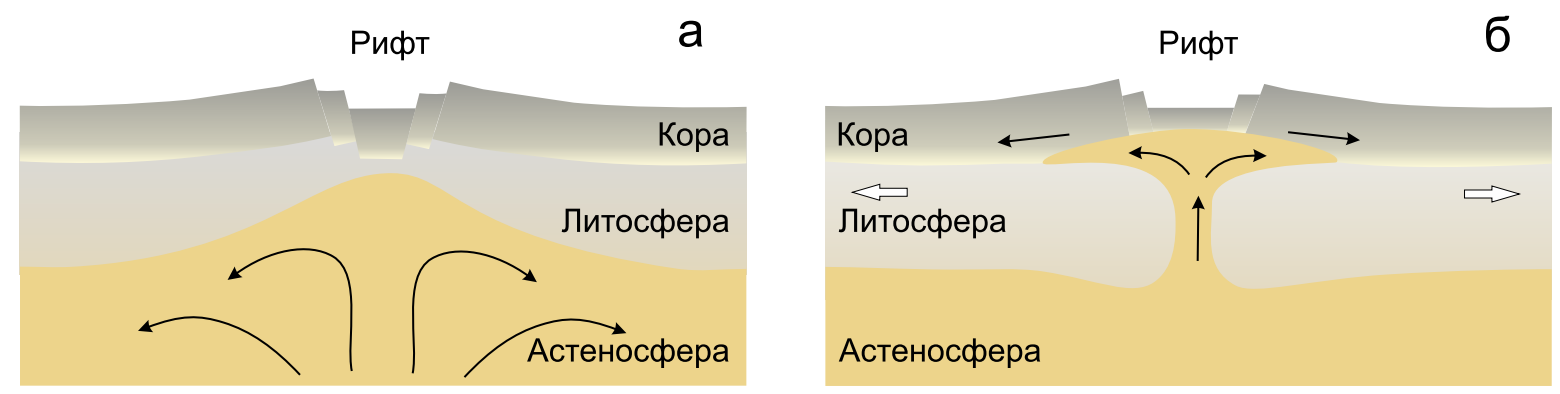

Рис. 3. Модели «активного» (a) и «пассивного» (б) механизмов рифтогенеза [Turcotte, Emerman, 1983].

$a$ - восходящая мантийная конвекция утоняет литосферу, приводя к коровому сводообразованию (механизм конвекции); б - растягивающие напряжения разрывают континентальную литосферу (механизм тектонического стресса). Мантийный диапир проникает до основания коры, приводя к ее утонению.

Fig. 3. Models of "active" (a) and "passive" (б) rift mechanisms [Turcotte, Emerman, 1983].

$a$ - ascending mantle convection thins the lithosphere causing crustal doming (convection mechanism); $\sigma$ - tensional stresses cause the failure of the continental lithosphere (mechanism of tectonic stress). A mantle diaper penetrates to the base of the crust causing crustal thinning.

результате движения литосферы и других оболочек Земли. Причины создания конвективной нестабильности в низкоскоростных доменах верхней мантии часто не ясны и могут быть постулированы в рамках различных гипотез, впрочем требующих аргументации. Происхождение областей плавления верхней мантии удается объяснить при их рассмотрении как вероятных производных преобразования первичных расплавных аномалий. Такие верхнемантийные аномалии приобретают статус вторичных.

Разделяя подлитосферные расплавные аномалии по происхождению на первичные и вторичные (рис. 5), мы связываем первые с процессами в нижней мантии (на границе ядра или переходного слоя), вторые - с процессами в верхней мантии (в низкоскоростных доменах 200-410 км и/или 50-200 км). Все четыре типа расплавных аномалий могут обеспечить термальное утонение литосферы, соответствующее, по определению, «активному» рифтогенезу. В сущности, под термином «активный» в нашем определении понимается не рифтовая структура, а расплавная аномалия, воздействующая на основание литосферы. Отдельно стоят процессы «пассивного» деформирования литосферы с растяжением (рифтогенез) и сжатием

\section{ПОДЛИТОСФЕРНЫЕ - ЛИТОСФЕРНЫЕ ИСТОЧНИКИ ВУЛКАНИЗМА}

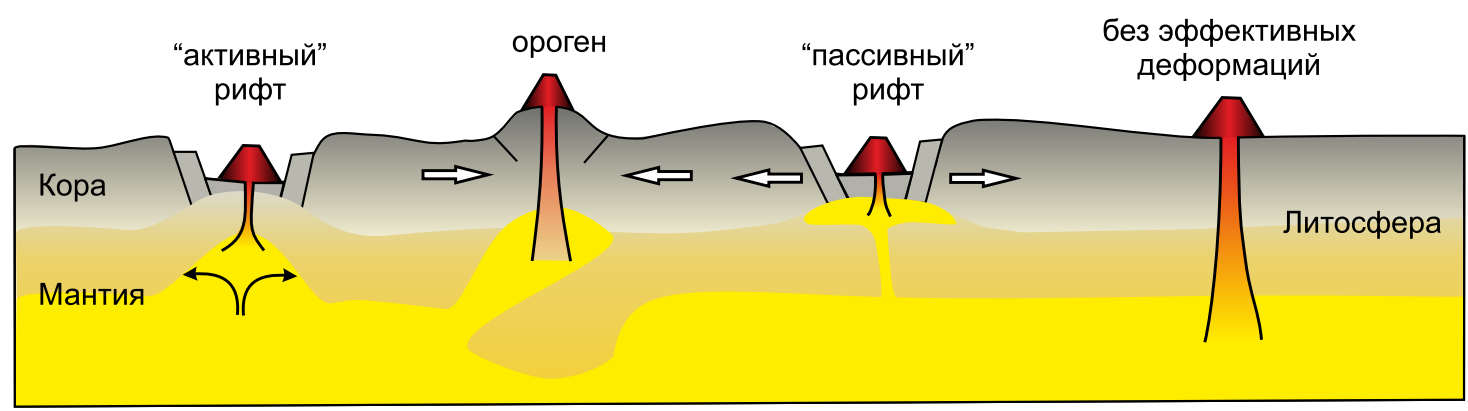

Рис. 4. Четыре типа источников, характеризующих развитие процессов магмообразования в подлитосферной мантии с вовлечением или без вовлечения в плавление литосферного материала. Выплавки из литосферных источников имеют самостоятельное значение либо сочетаются с выплавками из более глубокой мантии.

Fig. 4. Four types of sources that characterize the development of magmatic processes in the sub-lithospheric mantle with / without involvement of the lithospheric material in melting. Liquids from the lithospheric sources are either independently important or combined with melts from the deeper mantle. 


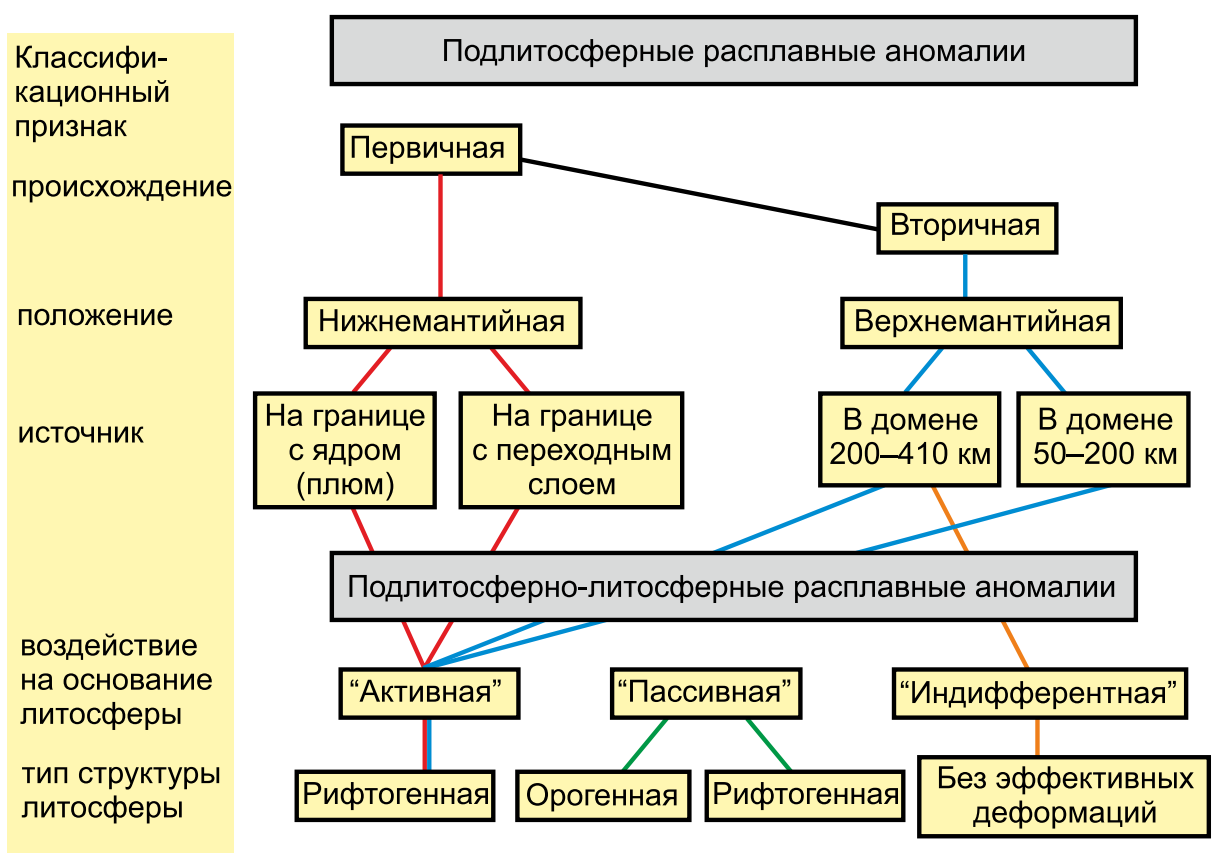

| Рис. 5. Диаграмма соотношений подлитосферных и подлитосферно-литосферных расплавных аномалий.

Fig. 5. Diagram of relationships between the sub-lithospheric and sub-lithospheric-lithospheric melting anomalies.

(орогенез). В нашем определении в качестве «пассивной» понимается не рифтовая или орогенная структура, а расплавная аномалия, образующаяся вследствие деформаций литосферы.

Изучение магматизма Азии показало также проявление «индифферентных» отношений между подлитосферной расплавной аномалией и литосферой. Пример - обширное вулканическое плато Дариганга (Юго-Восточная Монголия), образовавшееся без существенных признаков деформаций коры. На этом плато имеются линии вулканических аппаратов и дайки, свидетельствующие о ее слабом северо-западном растяжении. Вулканизм этой территории пространственно связан с низкоскоростной аномалией, ярко выраженной на глубине 250300 км и относящейся к Забайкальскому низкоскоростному домену.

В длительно развивающейся зоне конвергенции океаническая плита может погружаться в переходный слой и далее в нижнюю мантию, вызывая обратный поток горячего материала. Таким образом, расплавная аномалия зоны конвергенции может иметь первичную природу. Во внутренней части континента расплавная аномалия подлитосферной верхней мантии может быть связана, с одной стороны, с плюмом или аномалией переходного слоя мантии, с другой - с рифтогенезом или орогенезом в литосфере. Отнесение вулканических пород какой-либо территории к тому или иному типу расплавных аномалий требует обоснования с исполь- зованием моделей сейсмической томографии высокого разрешения и согласования выявленных низкоскоростных аномалий с распределением мантийного вулканизма.

\section{4. МОДЕЛИ ФЛЮИДНОЙ МЕХАНИКИ В ПРИЛОЖЕНИИ К РАСПЛАВНЫМ АНОМАЛИЯМ}

Поверхность литосферы может смещаться относительно ядра, нижней мантии, переходного слоя или астеносферы. Астеносфера, по определению, обладает низкой вязкостью и высокой текучестью. Любой поток в астеносфере будет направлен приблизительно горизонтально из-за больших горизонтальных размеров литосферных плит, составляющих тысячи километров. В модели астеносферного потока рассматривается одномерное течение ньютоновской вязкой жидкости в канале между параллельными пластинами. Наличие расплавной области в астеносфере приводит к относительному снижению вязкости и усилению текучести. Таким образом, расплавная аномалия в астеносферной мантии представляет собой область, чувствительную к движению литосферы.

Соотношения между движущейся литосферой и подлитосферной мантией служат объектом исследований флюидной механики. Для объяснения латерального смещения материала расплавных аномалий Центральной Азии мы рассматриваем две вероятные модели: (1) модель одномерного 


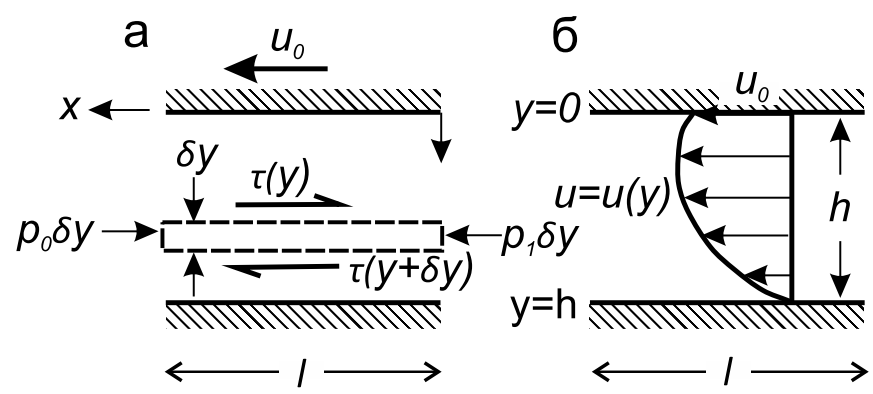

Рис. 6. Баланс сил в слое флюида внутри канала с приложенным градиентом давления (a) и типичный профиль скорости (б) [Turcotte, Schubert, 2014] (объяснения в тексте).

Fig. 6. The balance of forces in the fluid layer inside the channel with an applied pressure gradient $(a)$, and a typical velocity profile (б) [Turcotte, Schubert, 2014] (explanation in the text).

прямого подлитосферного потока в канале и (2) модель обратного потока. Обе обсуждались в работе [Turcotte, Schubert, 2014].

В подлитосферном канале флюид движется со скоростью $u$ в направлении $x$ в канале толщиной $h$. Горизонтальная скорость меняется только по вертикали: $u=u(y)$, где $y$ обозначает расстояние от верхней границы $(y=0)$. Поток создается либо приложенным горизонтальным градиентом давления $\left(\rho_{o}-p_{1}\right) / l(l-$ горизонтальная длина участка канала, $\rho_{1}$ - давление на входе в разрезе, $\rho_{o}$ - давление на выходе из разреза), либо движением одной из стенок (предполагается, что верхняя граница $y=0$ име- ет заданную скорость $u=u_{0}$, а нижняя граница $y=h$ неподвижна) (рис. 6).

Поток может быть обусловлен также сочетанием градиента давления и заданной скорости движения стенки. Вследствие сдвига или градиента профиля скоростей, напряжение сдвига $\tau$ (сила на единицу площади) проецируется на горизонтальные плоскости в жидкости и на стенки каналов. Простой поток, сопровождающий движение литосферы, известен как поток Куэтта (рис. 7, a). В общем случае (без движения литосферы) профиль его скорости представляет собой параболу, симметричную относительно средней линии канала (рис. 7, б). Механизм волочения (drag) эффективен, если вязкость снижается от литосферы к астеносфере постепенно. При резком отличии вязкостных параметров литосферы и астеносферы фактор механизма волочения, обеспечивающего динамическую связь между литосферой и астеносферой, может быть неэффективным. В этом случае низковязкая часть потока Куэтта проскальзывает под литосферой с опережающим выдвижением верхней части астеносферного слоя относительно его нижней части. Хотя с глубиной вязкость мантии возрастает, возможен вариант образования локального слоя низкой вязкости над кровлей переходного слоя (например, из-за наличия 30-километрового слоя, обогащенного $\mathrm{H}_{2} \mathrm{O}$ [Karato, 2012]) и, соответственно, опережающего выдвижение нижней части астеносферного слоя относительно его верхней части. В обоих случаях потоки астеносферы с меняющейся вязкостью могут проявляться в прогрессирующей миграции вулканизма (рис. 8).
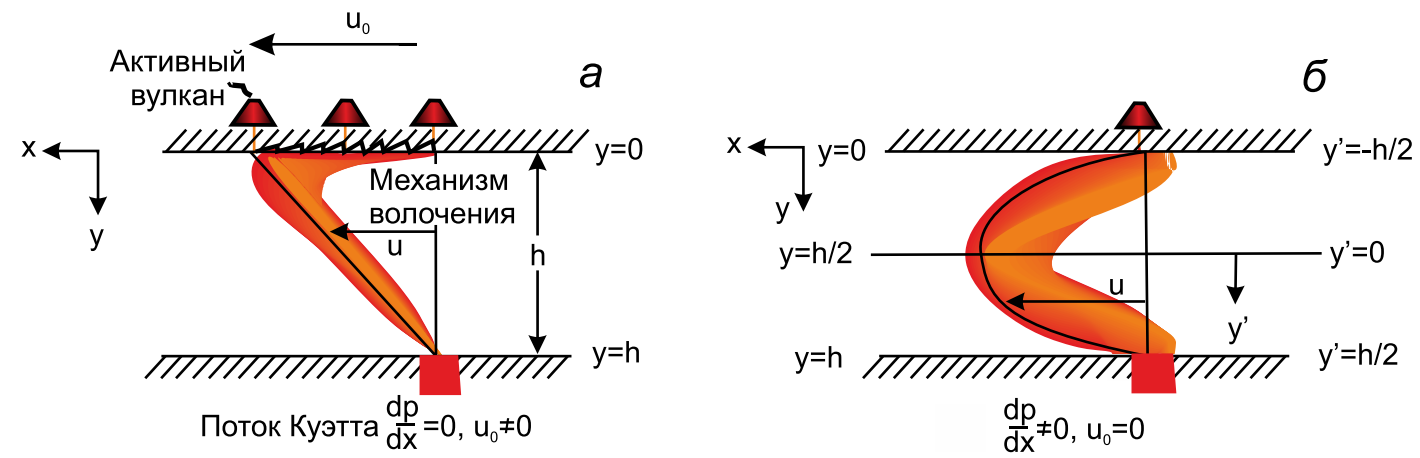

Рис. 7. Отклонение расплавной аномалии потоком Куэтта постоянной вязкости в канале под движущейся литосферой $(a)$ и потоком с градиентом давления под стационарной литосферой (б). На обеих панелях смещается материал слабых расплавных аномалий. Графическое представление смещений по моделям [Turcotte, Schubert, 2014] (объяснения в тексте).

Fig. 7. Deviations of a melting anomaly by a Couette flow (constant viscosity) in a channel beneath the moving lithosphere (a) and by a flow with a pressure gradient beneath the stationary lithosphere (б). Both panels show displacements of the material in weak melting anomalies. Graphical representations of the displacements correspond to the model described in [Turcotte, Schubert, 2014] (explanation in the text). 

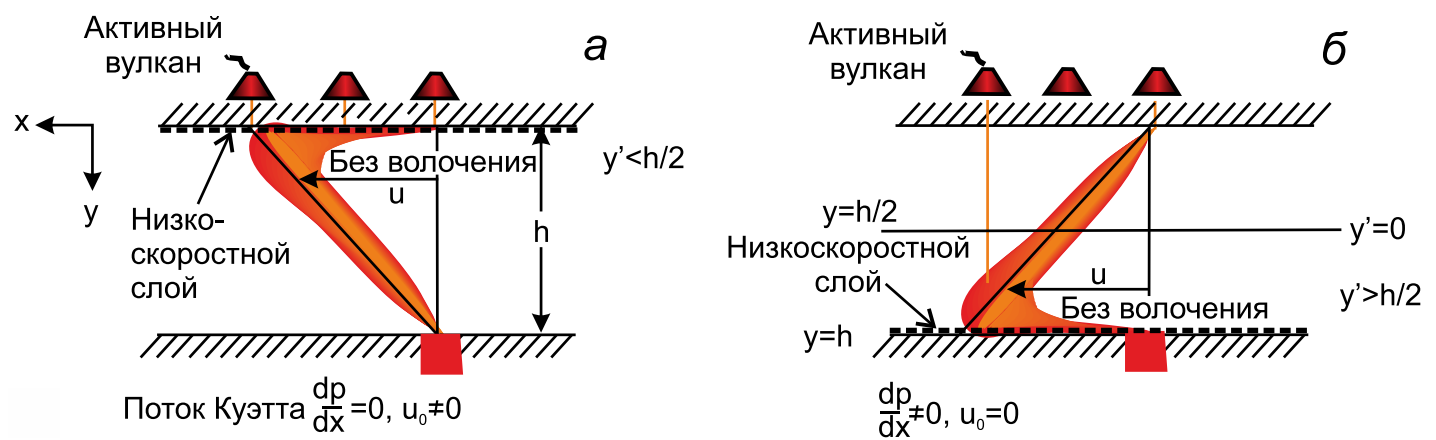

Рис. 8. Пограничное проскальзывание астеносферного материала при уменьшении вязкости под литосферой (a) или над переходным слоем (б).

Fig. 8. Boundary slip of the asthenosphere material due to reduced viscosity beneath the lithosphere $(a)$ and above the transition layer (б).

В модели движения литосферной плиты с астеносферным течением противоположной направленности (рис. 9) жесткая литосфера толщиной $h_{\mathrm{L}}$ смещается со скоростью $u_{0}$. Под литосферой находится астеносферный слой толщиной $h$ с однородной вязкостью $\mu$. В основании астеносферы мантия стационарна, т.e. $\mathrm{u}=0$ при $y=h$. Сохранение масс требует, чтобы движение литосферы в направлении +x балансировалось противоположным течением астеносферы.

В общем случае вулканизм маркирует на земной поверхности расплавную аномалию, проходящую от переходного слоя (мезосферы) через астеносферный слой. Извергающийся вулкан соответствует центру низкоскоростной мантийной анома- лии. Если аномалия существует малый временной интервал (первые млн лет), она не испытывает существенного латерального смещения. Вулканизм будет пространственно совпадать с центром низкоскоростной мантийной аномалии переходного слоя и в том случае, если после вулканического извержения литосфера не приводилась в движение или ее движение было несущественным.

На рис. 9 приведены варианты соотношений расплавных аномалий, проходящих через астеносферу, в зависимости от гидростатического напора в расплавной колонне. На панели $(a)$ схематично изображено сечение слабой расплавной аномалии переходного слоя. Из-за слабого гидростатического напора она изгибается обратным астеносферным

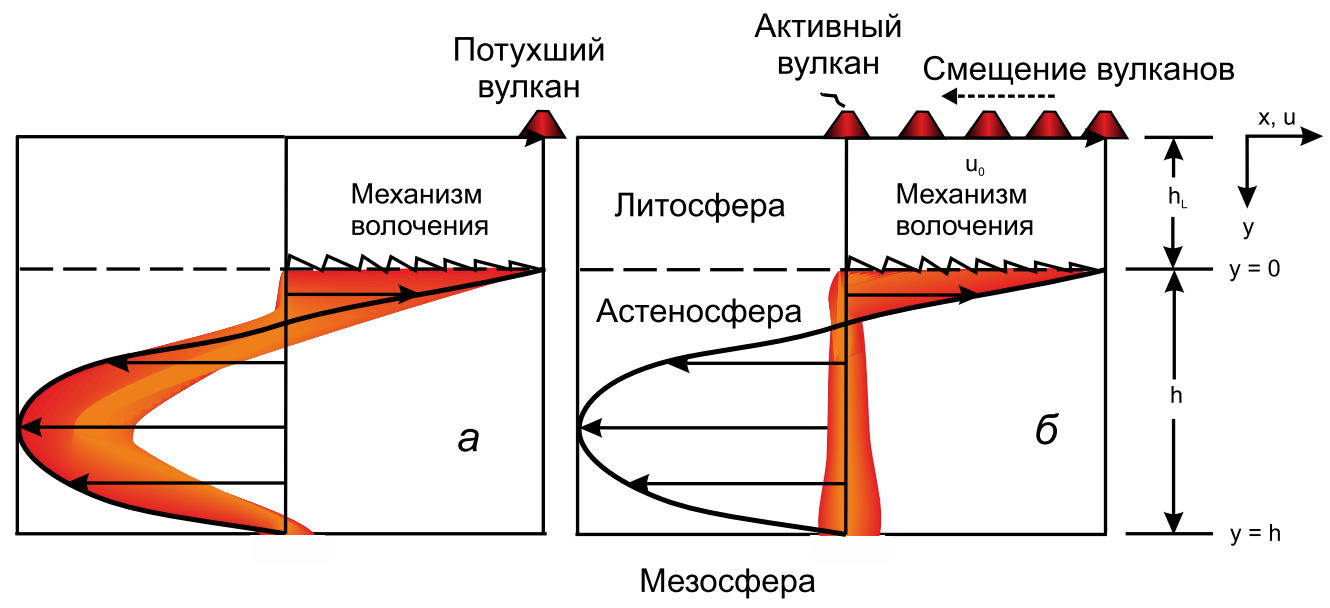

Рис. 9. Поведение слабой (a) и сильной (б) расплавных аномалий в обратном астеносферном потоке, инициируемом под движущейся литосферой. Графическое представление векторов обратного потока дано по модели [Turcotte, Schubert, 2014] (объяснения в тексте).

Fig. 9. Behavior of weak (a) and strong (б) melting anomalies in an asthenospheric counter flow initiated under the moving lithosphere. Graphical representations of the offset vectors correspond to the model described in [Turcotte, Schubert, 2014] (explanation in the text). 
потоком. На панели (б) приведена схема поднимающегося горячего материала расплавной аномалии с сильным гидростатическим напором. При наличии обратного потока под движущейся литосферой ее след устойчиво трассируется цепочкой вулканов, мигрирующей в противоположном направлении относительно движущейся литосферы. Расплавная колонна не изгибается.

\section{3. НОВЕЙШИЙ ГЕОДИНАМИЧЕСКИЙ ЭТАП}

В новейший геодинамический этап объединяются геологические процессы и силы, получившие выражение в современном состоянии мантии и коры при однонаправленном развитии во временном интервале с момента запуска до настоящего времени. Этот этап начался во время последней фанерозойской (среднемеловой) палеомагнитной суперхроны, длившейся 118-83 млн лет назад. Предполагается, что «Тихий меловой период» соответствовал разогретому («суперплюмовому») состоянию мантии, отразившемуся в максимальной скорости образования океанической коры, максимальном парниковом эффекте, максимальном поднятии уровня моря и высокой морской биопродуктивности [Larson, 1991a, 1991b; Larson, Erba, 1999; Tatsumi et al., 1998; Condie, 2001; Jenkyns et al., 2004; Courtillot, Olson, 2007; Trabucho Alexandre et al., 2010]. Время 90 млн лет назад было обозначено уникальным для поздней Земли коматиитовым магматизмом o. Горгона [Arndt et al., 2008]. В численной глобальной модели лавинообразного обрушения материала на разделе 660 км, исходящей из «горячего» состояния мантии мелового периода [Machetel, Humler, 2003], принимается исходный слабый обмен между слоями мантии около 430 млн лет назад, распространение тепловых потоков около 125 млн лет назад (в течение 30 млн лет) и около 60 млн лет назад, а также образование теплового потока на границе ядро-мантия 46-37 млн лет назад.

Возраст коры современных океанов Земли в основном не превышает 180 млн лет [Sandwell et al., 2005]. Отдельные фрагменты возрастом до 280 млн лет сохранились в Средиземноморье и краевых частях Северной Атлантики [Müller et al., 2008]. Считается, что вся более древняя океаническая кора субдуцирована в мантию, обдуцирована на континенты или находится в аккретированных террейнах. Направления и скорости движения плит в общем согласуются с моделью движущих сил, создающихся за счет мантийных плотностных и вязкостных неоднородностей. Ретроспективный анализ кинематики плит в координатах фиксированных горячих пятен свидетельствует о высокой кинетической энергии движения плит, существовавшей в интер- вале 100-84 млн лет назад и о последующем снижении кинетической энергии, происходившем главным образом за счет уменьшения спредингово-субдукционного компонента движений плит при относительно постоянном компоненте их трансформно-вращательных движений. Предполагается, что минимум кинетической энергии литосферных плит, достигнутый около 43 млн лет назад, поддерживается до настоящего времени [Lithgow-Bertelloni, Richards, 1998].

Начальная глобальная точка отсчета заключительного геодинамического этапа 90 млн лет назад определяется по морским записям ${ }^{87} \mathrm{Sr} /{ }^{86} \mathrm{Sr}$, в которых проявлен результирующий эффект континентальных (коровых) и океанических (мантийных) процессов. Преобладающее растворение в морской воде переработанного континентального материала, обогащенного радиогенным ${ }^{87} \mathrm{Sr}$, обеспечивалось в условиях конвергенции и выражено верхней огибающей линией главного тренда. Эпизодическое усиление эффекта растворения океанического материала проявлялось в относительном снижении ${ }^{87} \mathrm{Sr} /{ }^{86} \mathrm{Sr}$ в условиях дивергенции и представлено нижней огибающей линией главного тренда. Вдоль главного тренда роль корового стронция снижалась в раннем и среднем фанерозое и возрастала в позднем фанерозое, роль мантийного стронция, наоборот, увеличивалась в раннем и среднем фанерозое, а в позднем фанерозое снижалась. Интегральный вклад коровой и океанической составляющих резко менялся в изгибе главного тренда. Дивергентному минимуму ${ }^{87} \mathrm{Sr} /{ }^{86} \mathrm{Sr} 160$ млн лет назад соответствовала глобальная структурная перестройка, сопровождавшаяся образованием новой литосферной плиты в южной части Палеопацифика и закрытием Монголо-Охотского залива в его северо-западной части. Около 90 млн лет назад размах вариаций ${ }^{87} \mathrm{Sr} /{ }^{86} \mathrm{Sr}$ был несущественным. Нижнее ограничение главного тренда практически соединилось с верхним ограничением. В целом нисходящая раннесреднефанерозойская часть главного тренда сменилась позднефанерозойской восходящей частью около 90 млн лет назад с переходными процессами, имевшими место со 180-160 млн лет назад (рис. 10).

Глобальный переход от раннесреднефанерозойского к позднефанерозойскому геодинамическому этапу преимущественно в середине мела имел региональные следствия в области конвергенции плит Пацифика и Азии, в Центральной Азии и в области Индо-Азиатской конвергенции. Подробный анализ геохронологических данных о возрасте магматических комплексов этого перехода на разных территориях приводился в наших работах ранее. Здесь мы подчеркнем особенности смены мелового магматизма в Центральной Монголии, в 

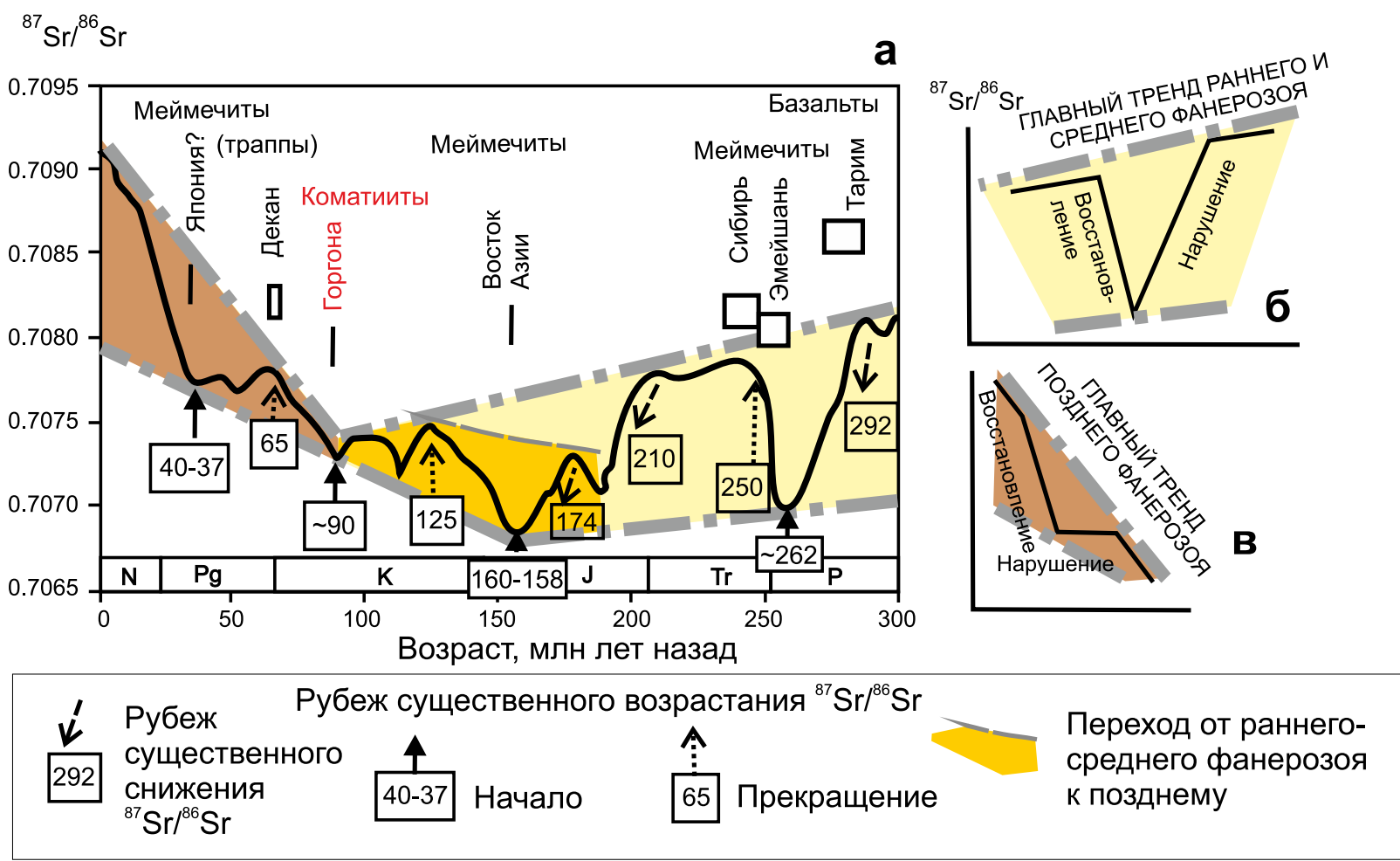

Рис. 10. Главные тренды вариаций ${ }^{87} \mathrm{Sr} /{ }^{86} \mathrm{Sr}$ в морской воде раннего, среднего и позднего фанерозоя.

На панели $(a)$ изгиб верхней огибающей (конвергентной) линии тренда около 90 млн лет назад соответствует начальной точке отсчета новейшего глобального геодинамического этапа. Изгиб нижней огибающей (дивергентной) линии тренда около 160 млн лет назад означает предшествующую глобальную структурную перестройку. Врезки (б) и (в) иллюстрируют нисходящий и восходящий характер главного тренда. Использована линия морских записей из работ [McArthur et al., 2001, 2012].

Fig. 10. The main sea water trend of ${ }^{87} \mathrm{Sr} /{ }^{86} \mathrm{Sr}$ variations in the Early, Middle and Late Phanerozoic.

(a) - bending of the upper envelope (convergent) line of the trend at ca. $90 \mathrm{Ma}$ corresponds to the initial reference point of the latest global geodynamic stage. Bending of the lower envelope (divergent) line at ca. 160 Ma marks the preceding global structural reorganization. Inserts (6) and (8) illustrate descending and ascending parts of the main trend. The line of marine records is from [McArthur et al., 2001, 2012].

Юго-Восточной, Восточной, Северо-Восточной Азии и в Тянь-Шане.

В Центральной Монголии переход к новейшему этапу резко выражен. В связи с внутриплитной аккомодацией процессов межплитной конвергенции около 90 млн лет назад высококалиевые латиты из коровых источников сменялись умереннокалиевыми базальтами - из мантийных. Базальтовый вулканизм временного интервала 91-31 млн лет назад был производным активизации палеослэбовых фрагментов Гобийской системы закрывшихся Солонкерского и/или Урало-Монгольского палеоокеанов, а затем, начиная с 32 млн лет назад, был связан с развитием Хангайского орогена. Чередование умеренно- и высококалиевых лавовых извержений первого временного интервала новейшего геодинамического этапа укладывалось в длиннопериодные циклы 20 млн лет, а второго интервала - в короткопериодные циклы 2.5 млн лет (неоген) и 0.7-0.3 млн лет (квартер).
Начало новейшего геодинамического этапа просматривается и в Юго-Восточной, и в Восточной Азии. Прекращение надсубдукционного гранитоидного магматизма обширной территории юго-

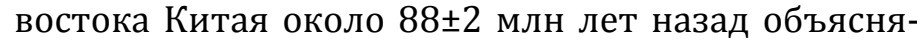
лось возникновением субдукционной пробки в западной части Тихого океана в это время или около 100 млн лет назад [Niu et al., 2015]. Структурная перестройка в Восточной Азии отчетливо выражена в распределении бассейнов седиментации [Kirillova, 1997, 2000]. Резкая смена магматизма зарегистрирована на п-ове Шандунь, в восточной части СиноКорейского кратона [Хu et al., 2004]. В интервале 90-75 млн лет назад здесь имел место амагматичный временной интервал, отделявший позднефанерозойские извержения базальтов от контрастного интрузивного гранитного и базитового магматизма, в целом свойственный предшествовавшему раннесреднефанерозойскому этапу развития территории. По изотопным характеристикам неодима 
и стронция магматизм, предшествовавший перерыву, был производным обогащенной мантии и коры. После перерыва стали поступать базальтовые расплавы из источников обедненной мантии.

С переходом от Восточной к Северо-Восточной Азии картина меняется. В Северо-Восточной Азии, на северной и западной континентальных окраинах Охотского моря были активны Охотско-Чукотский и Восточно-Сихотэ-Алинский вулканические пояса андийского типа. Первый датирован временным интервалом 110-75 млн лет назад, второй интервалом 95-65 млн лет назад (см. дискуссию [Kotlyar, Rusakova, 2004] и более поздние выводы [Akinin, 2012]). Первый вулканический пояс не имеет отчетливой связи с новейшим геодинамическим этапом, второй - хорошо вписывается в его начало. Существенное отличие вулканических поясов заключается в разной роли последующих процессов, получивших выражение в извержениях лав внутриплитного типа. К северу от Охотского моря вулканизм Охотско-Чукотского пояса сменялся переходным вулканизмом островодужного-внутриплитного типа 86-72 млн лет назад и продолжался извержениями внутриплитных базальт-трахибазальтовых и трахибазальт-трахириолитовых комплексов до 54 млн лет назад [Belyi, Belaya, 1998; Kotlyar, Rusakova, 2004]. К западу от Охотского моря вулканизм Восточно-Сихотэ-Алинского пояса сменялся в раннем-среднем кайнозое переходным вулканизмом островодужного-внутриплитного типа, а затем извержениями внутриплитных базальт-трахибазальтовых комплексов, продолжавшимися в позднем кайнозое до 3 млн лет назад. Такая длительная «внутриплитная» активность на континентальной окраине сочеталась с субдукционными процессами со стороны Пацифика.

Подобно Охотско-Чукотскому поясу, нет очевидной связи с новейшим геодинамическим этапом и в эволюции мел-палеогенового вулканизма Тянь-Шаня. В Южном Тянь-Шане, во впадине Туюн, на протяжении временного интервала 122-46 млн лет назад извергалась серия расплавов пикробазальт-базанит-фонотефрит-фонолит - производная плавления малоглубинного безгранатового источника мантии. В Северном и Срединном ТяньШане в интервале 61-53 млн лет назад был представлен ряд расплавов фоидит-базанит-трахибазальт-базальт-андезибазальт. Базаниты и фоидиты выплавлялись в глубокой части мантии гранатовой фации, а трахибазальты, базальты и андезибазальты - в нижней коре. Мы предполагаем, что выявленное отличие мел-палеогеновых серий Южного, Северного и Срединного Тянь-Шаня отражало разный характер активизации мантийных и коровых неоднородностей, образовавшихся в про- цессе позднепалеозойского закрытия Туркестанского палеоокеана.

\section{4. ДВИЖЕНИЕ ЛИТОСФЕРЫ АЗИИ, СТРУКТУРНЫЕ ПЕРЕСТРОЙКИ НА АЗИАТСКО-ТИХООКЕАНСКОЙ ГРАНИЦЕ}

Характер современных деформаций в Азии был воспроизведен в физических экспериментах [Tapponnier et al., 1982; Fournier et al., 2004]. Экструзивная тектоника во фронте Индийского индентора моделировалась с использованием пластины, ограниченной с левой стороны при свободном деформировании правой стороны. Результирующая правосторонняя экструзия материала сопоставлялась с крупномасштабной деформацией Китайского и Индокитайского блоков.

Гипотеза о восточном и юго-восточном движении азиатских блоков [Halim et al., 1998] была дополнена данными по пространственно-временному распределению вулканизма, сейсмичности и данными GPS-геодезии, свидетельствующими об общем делении Азии на стабильную часть и тектонически-нестабильные территории - области рассредоточенных деформаций значительной ширины и протяженности [Calais et al., 2003, 2006; Kreemer et al., 2003; Jin et al., 2007; Sankov et al., 2011]. По преобладанию растяжения или сжатия тектонически активные (подвижные) системы кайнозоя были подразделены, соответственно, на рифтовые и орогенные [Rasskazov et al., 1998]. Первые находятся во Внутренней Азии (Байкальская и Циркум-Ордосская, или Шаньси) и на восточной континентальной окраине (Восточно-Китайская), последние (Центрально-Азиатская и Олекмо-Становая) - соответственно, во фронте Индо-Азиатской и Азиатско-Североамериканской зон конвергенции. Фактически Байкальская рифтовая система расположена между орогенными системами, пространственно связанными с различными коллизионными зонами, а Циркум-Ордосская и Восточно-Китайская рифтовые системы - между Индо-Азиатской зоной коллизии и рифтогенно-спрединговыми областями зоны конвергенции Пацифика и Евразии (ОхотскоЯпонско-Филиппинской и Южно-Китайского моря) (рис. 11).

Характер тектонических деформаций отражается в современных движениях коры. При общем движении Стабильной Азии в восток-юго-восточном направлении с локальной скоростью около 3 смхгод-1 [Rotacher et al., 1996] она испытывает вращение по часовой стрелке вокруг полюса, расположенного на юге Евразии [Gatinsky, Rundquist, 2004]. Некоторые крупные относительно жесткие блоки Азии (Амурский, Южно-Китайский, Зонд- 


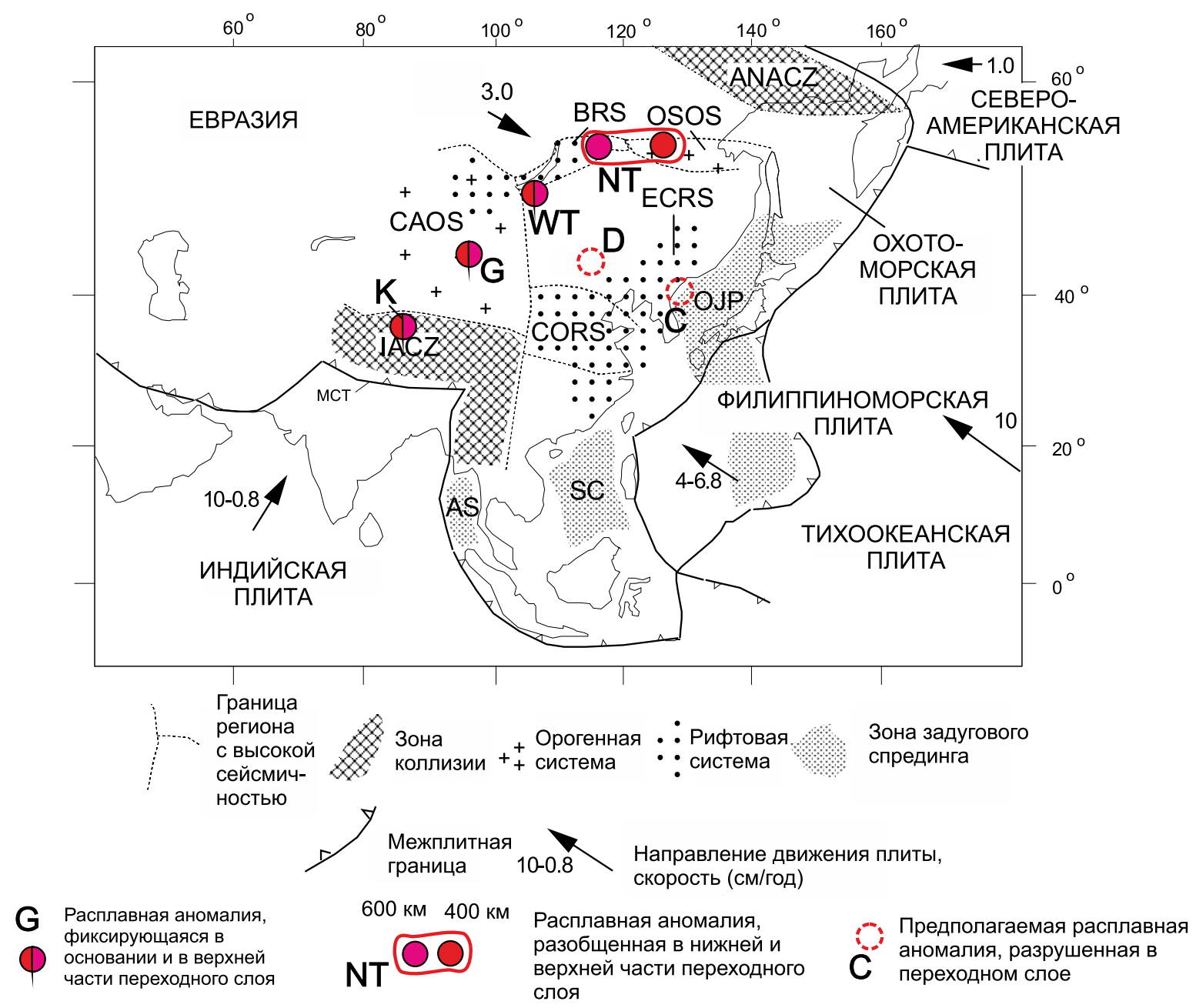

Рис. 11. Соотношения первичных расплавных аномалий с позднекайнозойскими подвижными системами в восточной части Евразии.

Коллизионные зоны: IACZ - Индо-Азиатская, ANACZ - Азиатско-Североамериканская. Орогенные системы: CAOS - ЦентральноАзиатская, OSOS - Олекмо-Становая. Рифтовые системы: BRS - Байкальская, CORS - Циркум-Ордосская (Шаньси), ECRS - Восточно-Китайская. Глубоководные впадины в зоне задугового рифтогенеза и спрединга: OJP - Охотско-Японско-Филиппинская, SC Южно-Китайская, AS - Адаманского моря. Первичные расплавные аномалии переходного слоя: G - Гобийская, WT - ЗападноЗабайкальская, NT - Северо-Забайкальская, K - Куньлуньская, C - Чангбайская (предполагаемая), D - Дариганская (предполагаемая). Границы подвижных систем из работы [Rasskazov et al., 1998] с дополнениями. Пространственное положение расплавных аномалий G, WT и NT показано по работе [Rasskazov, Chuvashova, 2016]. Для аномалий K, D и С см. пояснения в тексте.

Fig. 11. Relations between the primary melting anomalies and the Late Cenozoic mobile systems in the Southeastern Eurasia.

Collision zones: IACZ - Indo-Asian, ANACZ - Asian-North American. Orogenic systems: CAOS - Central Asian, OSOS - Olekma-Stanovoi. Rift systems: BRS - Baikal, CORS - Circum Ordos (Shanxi), ECRS - East China. Deep basins in the zone of back-arc rifting and spreading: OJP Okhotsk-Japan-Philippine, SC - South China, AS - Andaman Sea. Primary melting anomalies in the transition layer: G - Gobi, WT - West Transbaikal, NT - North Transbaikal, K - Kunlun, C - Changbai (assumed), D - Dariganga (assumed). The boundaries of the mobile system are from [Rasskazov et al., 1998]. The spatial positions of the melting anomalies G, WT, and NT are shown according to [Rasskazov, Chuvashova, 2016]. Anomalies K, D, and C are explained in the text.

ский) также вращаются. Амурский блок перемещается относительно Стабильной Азии с вращением против часовой стрелки при угловой скорости $0.03^{\circ}$ млн лет ${ }^{-1}$ с полюсом на северной окраине Охотского моря $\left(58.8{ }^{\circ} \mathrm{N}, 157.7{ }^{\circ} \mathrm{E}\right)$. Подобное вращение с большей скоростью $\left(0.22^{\circ}\right.$ млн лет $\left.{ }^{-1}\right)$ определяется для Южно-Китайского блока по от- ношению к Евразии с полюсом в Северном Китае $\left(47.3^{\circ} \mathrm{N}, 126.8^{\circ} \mathrm{E}\right)$. Зондский блок вращается по часовой стрелке со скоростью $0.13^{\circ}$ млн лет ${ }^{-1}$ с полюсом в Индийском океане к западу от Австралии $\left(26.0^{\circ} \mathrm{S}, 80.4^{\circ} \mathrm{E}\right)$ [Kreemer et al., 2003]. Ордосский блок испытывал общее позднекайнозойское вращение против часовой стрелки [Xu, Ma, 1992]. По 
данным GPS-геодезии, бассейн Южного Байкала открывается в настоящее время со скоростью

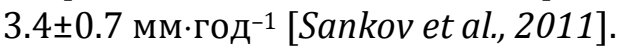

Отметим также, что районы Азии претерпевали сложные деформации с изменением условий растяжения и сжатия. Границы относительно стабильных блоков нередко испытывали сдвиговые смещения. По смене ориентировки трещинных извержений в северо-восточной части Байкальской рифтовой зоны зафиксирована раннеголоценовая смена поля напряжений. Подобным образом о кратковременных вариациях напряженно-деформированного состояния коры свидетельствуют данные продолжительных наблюдений GPS-геодезии. В северо-восточной части рифта Шаньси в 2003 г. не было обнаружено явных признаков растяжения, хотя в период наблюдений 1992-1996 гг. была определена скорость растяжения, сопоставимая с растяжением бассейна Южного Байкала

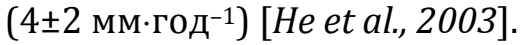

На континентальной окраине Восточной Азии тектонические условия быстро менялись в направлении с юга на север, от Корейского п-ова к о-ву Сахалин. В районе Корейского п-ова и южнее его Филиппиноморская плита никогда не была тесно соединена с Азией. Вдоль этой плиты проходила граница «свободной континентальной окраины», не препятствовавшей экструзивной тектонике, производной Индо-Азиатской зоны коллизии, как это предполагали П. Таппонье и др. [Tapponnier et al., 1982]. В отличие от этой плиты, Охотоморская присоединилась к Азии в середине эоцена и стала одним из азиатских террейнов к середине миоцена. Субдукция Тихоокеанской плиты, выраженная позднекайнозойским островодужным вулканизмом, сопровождалась задуговым растяжением коры в области Филиппинского, Японского и Охотского морей.

В середине кайнозоя Тихоокеанская плита испытывала боковое скольжение относительно Азии. Позднекайнозойская структурная перестройка Восточной Азии была обусловлена завершением аккреции фрагментов плиты Кула-Изанаги к континентальной окраине и переходом к субдукции Тихоокеанской плиты. На рубеже миоцена и олигоцена вулканизм был ограничен ослабленными шовными зонами континентальной литосферы, а в раннем миоцене, 22-17 млн лет назад, распространился в обширном регионе от Японии до Восточного Саяна. Такое пространственное перераспределение вулканизма свидетельствовало об определяющем влиянии на внутриплитные процессы Азии структурной перестройки ее восточной межплитной границы, которая привела к задуговому растяжению с откатом островных дуг Японии в сторону океана.
Переход к субдукции сопровождался задуговым раскрытием Японского моря около 15 млн лет назад с резким разворотом Юго-Западной Японии по часовой стрелке и образованием косой ХонсюКорейской слэбовой флексуры. Прямая ХоккайдоАмурская слэбовая флексура, совпадавшая с направлением конвергенции Тихоокеанской плиты и Азии, образовалась в результате последующей субдукции при встречном движении Тихоокеанской плиты со скоростью около 10 см/год и Азии, современная скорость которой в стабильной части составляет 3 см/год. Хоккайдо-Амурская флексура простирается от сочленения Японского и Курильского преддуговых желобов под Юго-Западным Хоккайдо до южной части Средне-Амурского бассейна. Другая слэбовая флексура начинается от сочленения Идзу-Бонинского и Японского желобов и проходит под Центральным Хонсю до юго-восточной окраины Корейского п-ова.

Отступление Японско-Идзу-Бонинского сочленения желобов и образование Хонсю-Корейской флексуры соответствовали открытию Японского моря. По палеомагнитным данным [Otofuji, 1996; Hoshi, Takahashi, 1999], северо-восточная часть о-ва Хонсю вращалась против часовой стрелки 21-18 млн лет назад, а юго-западная часть этого о-ва быстро развернулась по часовой стрелке около 15 млн лет назад. Смещение последней территории относительно современного положения было противоположным по отношению к движению Тихоокеанской плиты. Это согласуется с бывшим расположением желоба вдоль материка Азии и последующей структурной перестройкой перекрывающего края плиты за счет эффекта ролбэк.

Палеомагнитные исследования в Восточно-Сихотэ-Алинском вулканическом поясе показали вращение против часовой стрелки позднемеловых раннепалеогеновых толщ. Это явление объяснялось сначала левосторонними движениями вдоль субмеридиональных разломов. Дальнейший анализ данных выявил, однако, противоречие этой интерпретации палеомагнитным результатам, полученным для восточной окраины Северо-Китайского блока. Богопольская свита накапливалась с 53-51 млн лет назад на юго-восточном краю жесткого Монгольского блока без существенного вращения по отношению к Евразии. Вулканические породы, залегающие стратиграфически ниже (Sijanov Formation and Kisin Group), а также самые ранние игнимбриты позднемеловых монастырской и приморской серий Восточно-Сихотэ-Алинского вулканического пояса образовались во время разворота этого блока против часовой стрелки до $41^{\circ} \pm 16^{\circ}$. Вращение было направлено противоположно вращению восточной части Северо-Китайского блока, реконструированному для толщ конца раннего 
мела, позднего мела и постмеловых толщ. Это пространственное соотношение полученных данных свидетельствовало о движениях, повторившихся затем при раннесреднемиоценовом открытии Японского моря [Otofuji et al., 2003].

\section{5. БАЗОВЫЕ МОДЕЛИ СЕЙСМИЧЕСКОЙ ТОМОГРАФИИ БАЙКАЛО-МОНГОЛЬСКОГО РЕГИОНА}

Имеющиеся скоростные модели Азии, акцентированные в основном на территорию Китая и восток Азии, выявили расплавные аномалии, спроецированные из мантии на четвертичные вулканические поля [Lei, Zhao, 2005; Zhao, 2009; Wei et al., 2012]. Часть моделей [Huang, Zhao, 2006; Li et al., 2006; Chen et al., 2015b] построена с целью получения обзорной картины под большой территорией Азии с глубинами, захватывающими нижнюю мантию. В таких генерализованных моделях мелкого масштаба связь кайнозойских вулканических полей с низкоскоростными аномалиями не очевидна. Другая часть моделей имела локальное значение для ограниченных территорий в районах Южного Байкала, Сибирь [Zorin et al., 2003; Zhao et al., 2006], и Хангая, Монголия [Mordvinova et al., 2007; Chen et al., 2015a]. Оптимально сфокусированы на территории БайкалоМонгольского региона скоростные модели S-волн [Yanovskaya, Kozhevnikov, 2003; Kozhevnikov et al., 2014]. Для регистрации Гобийской, Западно-Забайкальской и Северо-Забайкальской расплавных аномалий новейшего геодинамического этапа эти модели приняты как базовые [Rasskazov, Chuvashova, 2016].

Модель Т.Б. Яновской и В.М. Кожевникова была построена до глубины 300 км в основном по цифровым данным системы IRIS с дополнительными данными, полученными в 1992-1993 гг. по временным цифровым станциям Российско-Американского проекта «Телесейсмическая томография Байкальского рифта», а также по оцифрованным аналоговым записям сейсмических станций Иркутска, Новосибирска и Южно-Сахалинска за период 1975-1987 гг. В модели под Сибирским кратоном отчетливо выражена высокоскоростная область глубин 200-300 км, протянувшаяся в субмеридиональном направлении западнее меридиана $105^{\circ}$ в.д., согласующаяся с такой же областью в более ранней модели высокого разрешения [Bijwaard et al., 1998]. При анализе соотношений локальных низкоскоростных аномалий модели Т.Б. Яновской и В.М. Кожевникова с распределением кайнозойского вулканизма были выделены крупные низкоскоростные домены верхней мантии: малоглубинный (до 200 км) Саяно-Хангайский и более глубинный (до переходного слоя) Забайкальский [Rasskazov et al., 2003].

Модель В.М. Кожевникова и др. [Kozhevnikov et al., 2014], включающая переходный слой, построена по представительной выборке дисперсионных кривых групповых скоростей основной моды волн Рэлея в пределах диапазона периодов колебаний 10-250 с. На общем фоне увеличения скорости поперечных волн с глубиной выявлено чередование низкоскоростных и высокоскоростных слоев с существенными латеральными вариациями. Генерализованные аномалии малых глубин мантии этой модели отличаются от детализированных аномалий модели [Yanovskaya, Kozhevnikov, 2003]. Целесообразно эту генерализованную модель использовать для регистрации низкоскоростных аномалий переходного слоя, а для глубин верхней мантии применять модель Т.Б. Яновской и В.М. Кожевникова, имеющую лучшее разрешение.

\section{6. ОБСУЖДЕНИЕ}

\section{1. ИДЕНТИФИКАЦИЯ ПЕРВИЧНЫХ РАСПЛАВНЫХ АНОМАЛИЙ ПЕРЕХОДНОГО СЛОЯ В БАЙКАЛО-МОНГОЛЬСКОМ РЕГИОНЕ}

В некоторых опубликованных работах в качестве источника кайнозойских вулканических пород Центральной и Восточной Азии априорно принимался плюм, хотя под этими территориями находится «холодный» переходный слой и нижняя мантия с относительно высокими скоростями сейсмических волн, а какие-либо нижнемантийные корни плюмовых расплавных аномалий отсутствуют [Castillo, 1988; Montelli et al., 2004; и дp.]. За счет сгружения слэбового материала фанерозойских палеоокеанов толщина переходного слоя в целом повышена, поэтому глубокая динамика регулируется здесь, скорее всего, слэбовыми лавинами из переходного слоя в нижнюю мантию [Maruyama et al., 2007]. Задача исследований новейшей геодинамики заключается в том, чтобы определить такие участки по пространственно-временным соотношениям низкоскоростных мантийных аномалий и вулканических полей. В переходном слое БайкалоМонгольского региона отчетливо различаются три низкоскоростные аномалии (Гобийская, ЗападноЗабайкальская и Северо-Забайкальская), имеющие ключевое значение для расшифровки новейшей геодинамики Азии (рис. 12).

Под Юго-Западной Гоби скорости локально снижаются в нижней части переходного слоя мантии (на глубине 600 км) на $4.5 \%$. В средней части переходного слоя, на уровне 500 км, картина сглаживается. Выше скорости локально снижаются непосредственно над переходным слоем (на глубине 


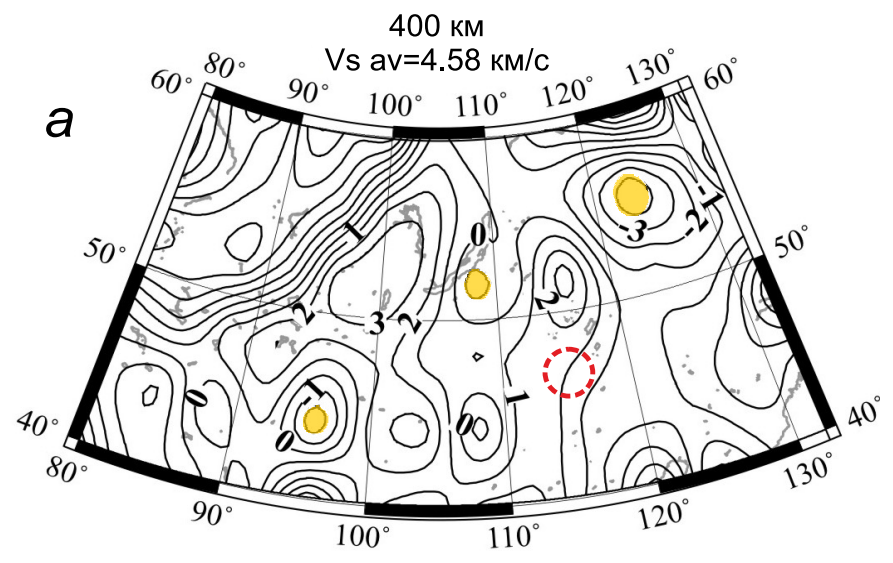

$600 \mathrm{KM}$

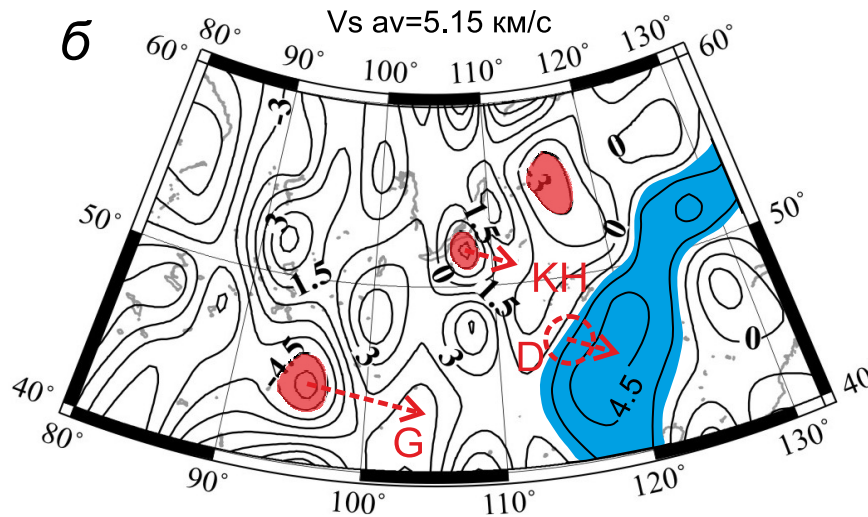

Низкоскоростная аномалия, связанная с основанием переходного слоя

Низкоскоростная аномалия, связанная с верхней частью переходного слоя

Смещение позднемеловых вулканических полей (G - Гобийского, $\mathrm{KH}$ - Хушиндинского) относительно аномалии переходного слоя

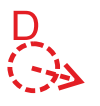

Предполагаемое исходное положение разрушенной Дариганской (D) расплавной аномалии переходного слоя и смещение позднемеловых вулканических полей

Нижняя часть стагнирующего слэба, разрушившего Дариганскую расплавную аномалию переходного слоя

Рис. 12. Соотношения между первичными низкоскоростными аномалиями переходного слоя и позднемеловыми вулканическими полями.

Вариации скорости поперечных волн показаны изолиниями в процентах относительно значений средней скорости Vs av. B качестве основы использованы сейсмотомографические изображения уровней 400 и 600 км модели В.М. Кожевникова и др. [Коzhevnikov et al., 2014].

Fig. 12. Relations between the primary low-velocity melting anomalies in the transition layer and the Late Cretaceous volcanic fields.

Shear-wave velocity variations are shown by isolines in percentage values relative to average values Vs av. The seismic tomography images at levels of 400 and $600 \mathrm{~km}$, according to the model in [Kozhevnikov et al., 2014], are used as a basis.

400 км). Центр обоих минимумов, связанных с переходным слоем, находится в координатах $44^{\circ}$ с.ш., $95^{\circ}$ в.д. Над этой низкоскоростной аномалией переходного слоя позднемеловые и кайнозойские вулканические породы не обнаружены. Позднемеловые вулканические поля смещены приблизительно на 550-600 км к востоку от центра Гобийской низкоскоростной аномалии переходного слоя.

Подобная аномалия переходного слоя фиксируется локальным снижением скоростей на глубинах 600 и 400 км под южным побережьем оз. Байкал с центром в координатах $52^{\circ}$ с.ш., $108^{\circ}$ в.д. Непосредственно над Западно-Забайкальской низкоскоростной аномалией переходного слоя позднемеловые и кайнозойские вулканические породы не известны. Породы возрастом 100-90 млн лет Хушиндинского вулканического поля смещены приблизительно на 350 км к востоку от центра Западно-Забайкальской низкоскоростной аномалии переходного слоя.

Северо-Забайкальская аномалия переходного слоя представлена локальным понижением скоростей на уровнях 600 км (55 с.ш., $116^{\circ}$ в.д.) и 400 км ( $55^{\circ}$ с.ш., $123^{\circ}$ в.д.). Позднемеловые вулканические породы, связанные с этой низкоскоростной аномалией, могут находиться в Алданском или Становом террейне. Их положение пока точно не идентифицировано. В области этой расплавной аномалии переходного слоя, между низкоскоростными неоднородностями 600 и 400 км, находится позднекайнозойское Удоканское вулканическое поле. 
При очевидной связи расплавных аномалий Байкало-Монгольского региона с движениями на межплитной границе Тихоокеанской плиты и Азии расшифровка подлитосферной динамики первичных и вторичных расплавных аномалий регионов Восточной Азии затруднена из-за нарушения первичных расплавных аномалий позднекайнозойским складированием океанического слэбового материала в переходный слой под этой территорией. Расплавные аномалии подлитосферной мантии и литосферы континентальной окраины Восточной Азии регистрируются только по низкоскоростным аномалиям верхней мантии и коры.

В Ханнуоба-Хэйлуцзянском регионе Северного Китая и сопредельной Юго-Восточной Монголии в плавление вовлекался верхнемантийный материал в виде кругового сегмента, обращенного выпуклой стороной от Тихоокеанской слэбовой лопасти на запад. Хорда сегмента протягивается на 1100 км от поля Тайханг (провинция Ханнуоба) на юго-югозападе до поля Нуоминхе (провинция Хэйлунцзян) на северо-северо-востоке. Эта линия ограничивает территорию западнее Главной гравитационной ступени восточной континентальной окраины Азии, известной на территории Китая под названием субмеридионального гравитационного линеамента (по Х.Й. Ма) или гравитационного линеамента большого Хингана-Тайханга (Daxinganlin-Taihang Gravity Lineament) (по другим авторам). Максимальная ширина средней части расплавного сегмента достигает 400 км. Вулканизм проявился здесь в начале новейшего геодинамического этапа, около 90 млн лет назад, и возобновлялся в интервале 33-17 млн лет назад и в последние 10 млн лет. Наиболее резко выраженная Восточно-Монгольская низкоскоростная аномалия (глубина 250 км) находится в осевой части сегмента под вулканическим полем Дариганга и вытянута в направлении с юго-юго-запада на северо-северо-восток. Эта низкоскоростная аномалия пространственно соответствует залеченной на уровне переходного слоя предполагаемой Дариганской первичной расплавной аномалии.

Главная гравитационная ступень восточной континентальной окраины Азии первоначально располагалась над западным краем стагнирующего слэба Кула-Изанаги, зафиксированным Дариганской расплавной аномалией, и к настоящему времени смещена относительно ее в результате движения литосферы приблизительно на 300-400 км. В отличие от первичных расплавных аномалий Байкало-Монгольского региона, Дариганская расплавная колонна обнаружила более сильный гидростатический напор. Подобно модели рис. 7, $a$, литосфера смещалась относительно предполагаемого исходного положения Дариганской аномалии пере- ходного слоя (возможно, с обратным подлитосферным потоком), но, в отличие от модели рис. 7, $a$, источник активизировался не под литосферой, а над переходным слоем в связи с дополнительным эффектом продвижения в переходном слое субдуцированного слэбового материала.

\section{2. СООТНОШЕНИЯ НИЗКОСКОРОСТНЫХ АНОМАЛИЙ ПЕРЕХОДНОГО СЛОЯ С ФРАГМЕНТАМИ ШВОВ ЗАКРЫВШИХСЯ ФАНЕРОЗОЙСКИХ ПАЛЕООКЕАНОВ}

По палеомагнитным данным [Kovalenko, 2010], геологические комплексы Монголии располагались значительно севернее Северо-Китайского блока в течение всего позднего палеозоя и раннего мезозоя. В палеозое Монголия, так же как и Сибирь, перемещалась с юга на север, с конца триаса до конца юры - с севера на юг, в мелу и кайнозое практически не перемещалась. Палеошироты формирования бимодальных рифтогенных магматических комплексов Монголии статистически не отличаются от палеоширот Сибирского кратона, по крайней мере, с конца перми (275-250 млн лет). Отсутствие широтных изменений палеополюсов в мелу и кайнозое не предполагает существенного меридионального перемещения Азии с этого времени.

Гобийская расплавная аномалия переходного слоя находится между фрагментами шовных зон закрывшихся Солонкерского и Урало-Монгольского палеоокеанов. Западно-Забайкальская и СевероЗабайкальская аномалии пространственно связаны с фрагментом закрывшегося Монголо-Охотского залива Палеопацифика (рис. 13).

Урало-Монгольский структурный шов разделяет территорию Монголии на Северный и Южный мегаблоки. Стабильный структурный ансамбль докембрийских каледонских террейнов Северного мегаблока, включающий Тувино-Монгольский микроконтинент, сформировался к концу ордовика. Этот мегаблок осложнен структурой МонголоОхотского залива Палеопацифика, последовательно закрывавшегося с запада на восток в позднем палеозое и мезозое с быстрым смыканием берегов в конце юры - начале мела [Sengör, Natal'in, 1996; Zorin, 1999; Kravchinsky et al., 2002]. Герцинские (силлурийско-каменноугольные) островные дуги Южного мегаблока (как части ЮжномонгольскоХинганской или Тяньшань-Южнохингалинской зоны) отделялись от Северо-Китайского кратона и аккретированных к нему террейнов Солонкерским швом [Yanshin, 1974; Belichenko, Boos, 1990; Tseden et al., 1992; Kozakov et al., 2007; Windley et al., 2007; Parfenov et al., 2003; Wan, 2010]. Солонкерский палеоокеан закрылся, по разным оценкам, в поздней перми или раннем триасе, во временном интервале 


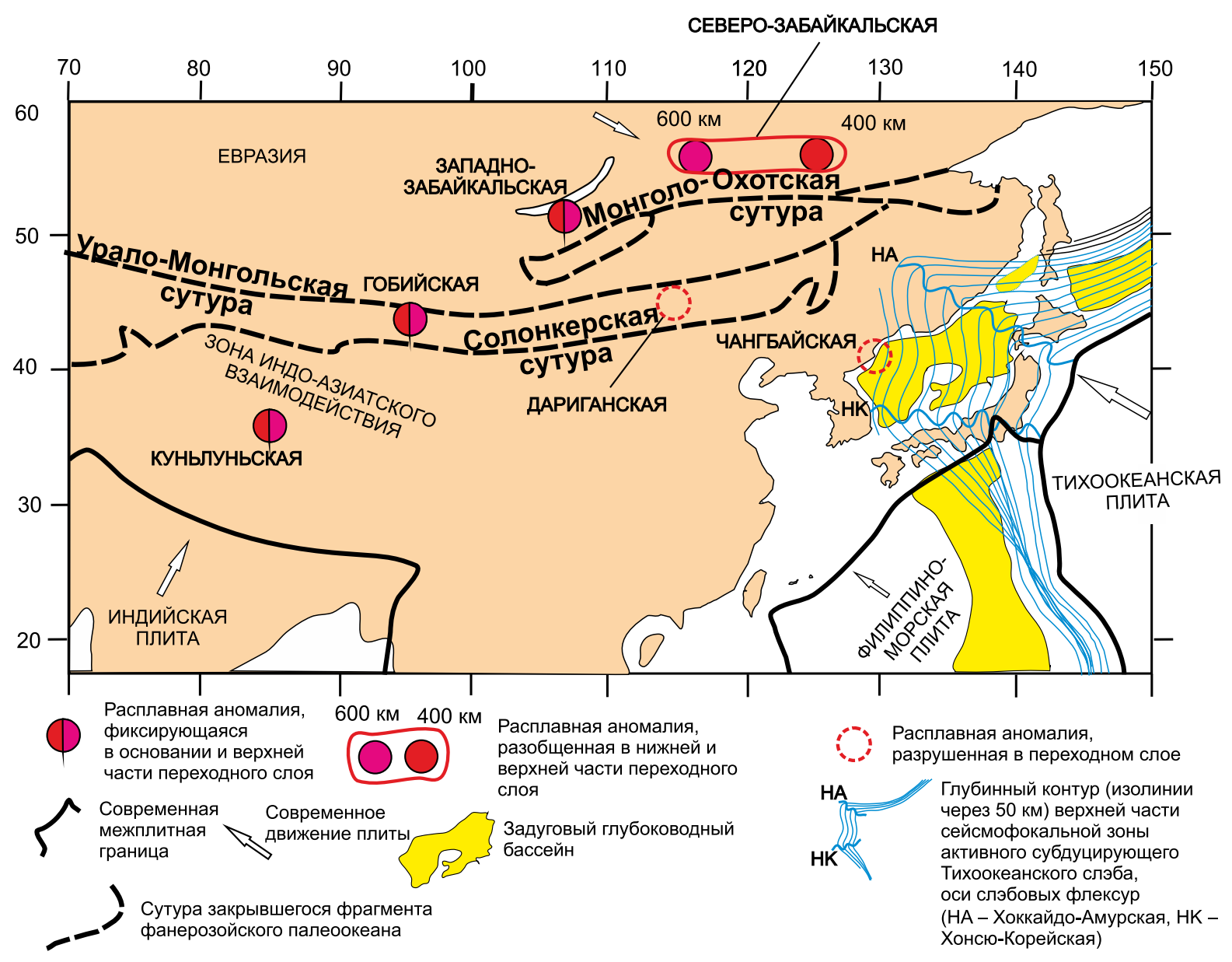

Рис. 13. Пространственное положение первичных низкоскоростных аномалий переходного слоя относительно шовных фрагментов закрывшихся фанерозойских палеоокеанов. Сейсмофокальная зона Тихоокеанского слэба показана по работе [Gudmundsson, Sambridge, 1998].

Fig. 13. Spatial positions of the primary low-velocity melting anomalies in the transition layer relative to the suture fragments of the closed Phanerozoic paleoceans. Seismic focal zone of the Pacific slab is shown after [Gudmundsson, Sambridge, 1998].

от 275 до 248 млн лет назад [Ruzhentsev et al., 1989; Kovalenko et al., 1996; SSengör, Natal'in, 1996; Parfenov et al., 2003; Wan, 2010; Qin et al., 2013; Zhou, Wilde, 2013; Han et al., 2015].

На новейшем геодинамическом этапе вулканизм охватил территорию между Солонкерским и УралоМонгольским швами во временном интервале 9131 млн лет назад и продвинулся севернее в область Тувино-Монгольского микроконтинента и западного замыкания Монголо-Охотского шва в последние 32 млн лет. Литосфера микроконтинента сжималась с образованием Хангайского орогена, а литосфера западного окончания Монголо-Охотского шва растягивалась с образованием впадин Центрально-Монгольского рифтового сегмента. Магматические расплавы щелочно-базальтового и андезитового состава извергались в поднимавшемся Хангайском орогене из источников, временная смена которых свидетельствовала о развитии про- цессов деламинации утолщенной части его литосферного киля, в отличие от Центрально-Монгольского рифтового сегмента, в районе которого изливались калиевые базальты, производные литосферно-астеносферных источников и показательные для процессов термального утонения литосферы.

Субдукция слэбового материала под Азию от закрывшихся фанерозойских палеоокеанических фрагментов сыграла важную подготовительную роль для образования расплавных аномалий переходного слоя новейшего геодинамического этапа. Слэбовый материал стагнировал в переходном слое мантии. Особые условия относительно низкой вязкости в нижней мантии в период мелового затишья 118-83 млн лет назад благоприятствовали нарушению 660-километровой границы и тепломассообмену между переходным слоем и нижней мантией. Мы предполагаем, что первичные Гобийская, 
Западно-Забайкальская и Северо-Забайкальская расплавные аномалии переходного слоя мантии явились результатом лавинного обрушения в нижнюю мантию слэбового материала и были образованы горячими обратными потоками, поднявшимися из нижней мантии непосредственно перед новейшим геодинамическим этапом или в начале этого этапа (т.е. около 90 млн лет назад).

\section{3. НАРУШЕНИЕ НИЗКОСКОРОСТНОЙ АНОМАЛИИ ПЕРЕХОДНОГО СЛОЯ ПОД СЕВЕРНЫМ ЗАБАЙКАЛЬЕМ}

В контексте настоящей работы мы допускаем, что обратные потоки астеносферы возникали при движении литосферы Азии преимущественно в областях мантийных расплавных аномалий и были динамически связаны с субдукцией океанических плит под Восточную Азию.

С одной стороны, модель прогрессирующей западно-северо-западной субдукции предполагает затягивание океанического материала под край континента, сопровождающееся обратным надслэбовым потоком, направленным от континента к океану. Под действием такого обратного потока над прямосубдуцирующей Хоккайдо-Амурской флексурой Тихоокеанского слэба литосфера северо-восточной части Байкальской рифтовой зоны растягивалась на границе архейского фундамента Сибирского кратона и аккретированных террейнов. С другой стороны, подобный поток создавался над Хонсю-Корейской слэбовой флексурой при откате от края континента и вращении ЮгоЗападной Японии во время открытия Японского моря (рис. 14).

Из гипотезы температурной зависимости фазового контроля глубинного положения границ переходного слоя следует, что термальный (термохимический) поток из нижней мантии должен одновременно идентифицироваться и в подошве, и в кровле переходного слоя. Пространственное совмещение низкоскоростных аномалий, связанное с обеими границами переходного слоя под Гоби и Байкалом, свидетельствует об отсутствии дифференциальных латеральных движений материала в этой части Внутренней Азии на новейшем геодинамическом этапе. И наоборот, взаимное пространственное разделение аномалий 600 и 400 км в Северном Забайкалье отражает боковое перемещение материала в переходном слое под Восточной Азией.

Результирующий вектор смещения низкоскоростной аномалии в верхней части переходного слоя относительно его нижней части направлен в Северном Забайкалье с запада на восток. Смещение складывалось из восточно-юго-восточного движения литосферы в соответствии с Азиатско-Тихо- океанской конвергенцией и поперечного северосеверо-восточного дрейфа. Суммарная амплитуда движения (около 400 км) и составляющие направления были сопоставимы с движением литосферы относительно Западно-Забайкальской аномалии переходного слоя. По-видимому, динамика Западно-Забайкальской и Северо-Забайкальской расплавных аномалий переходного слоя обеспечивалась одной причиной, хотя в районе Байкала движения имели место на уровне верхней мантии, а в Северном Забайкалье - на уровне переходного слоя.

Нарушение Северо-Забайкальской расплавной аномалии может быть следствием латерального движения материала в переходном слое под Восточной Азией, сопряженного с концентрированным затягиванием в переходный слой материала Тихоокеанского слэба вдоль прямосубдуцирующей Хоккайдо-Амурской флексуры. Не исключено, что переходный слой был нарушен в позднем мелу раннем палеогене в связи с более ранним погружением слэба Кула-Изанаги в процессе аккреции к окраине Азии Охотоморской плиты. Отделить эффекты слэба Кула-Изанаги со стороны Охотского моря и Тихоокеанского слэба со стороны Японского моря пока не представляется возможным.

Особенность динамики переходного слоя Северного Забайкалья, которая подчеркивается отсутствием нарушения переходного слоя в Гобийской и Западно-Забайкальской расплавных аномалиях, позволяет выдвинуть предположение о возможной причине выявленных различий. Первая аномалия находится на направлении погружения косой Хонсю-Корейской флексуры, две других - между Хоккайдо-Амурской и Хонсю-Корейской флексурами и на траверсе последней. Мы предполагаем, что отличие Гобийской и Западно-Забайкальской расплавных аномалий от Северо-Забайкальской связано с разной динамикой Хонсю-Корейской и Хоккайдо-Амурской флексур Тихоокеанского слэба: пассивным образованием первой при раскрытии Японского моря и активным образованием второй при прогрессирующем затягивании Тихоокеанского слэба в переходный слой по направлению конвергенции Тихоокеанской плиты и Азии.

\section{4. СООТНОШЕНИЯ ПЕРВИЧНЫХ РАСПЛАВНЫХ АНОМАЛИЙ И АСТЕНОСФЕРНЫХ ПОТОКОВ}

Регистрация низкоскоростных аномалий в верхней мантии непосредственно под четвертичными вулканическими полями служит в качестве аргумента для объединения вулканических пород с низкоскоростной структурой в единую расплавную аномалию, глубина которой оценивается по распространению низких скоростей на разные уровни 


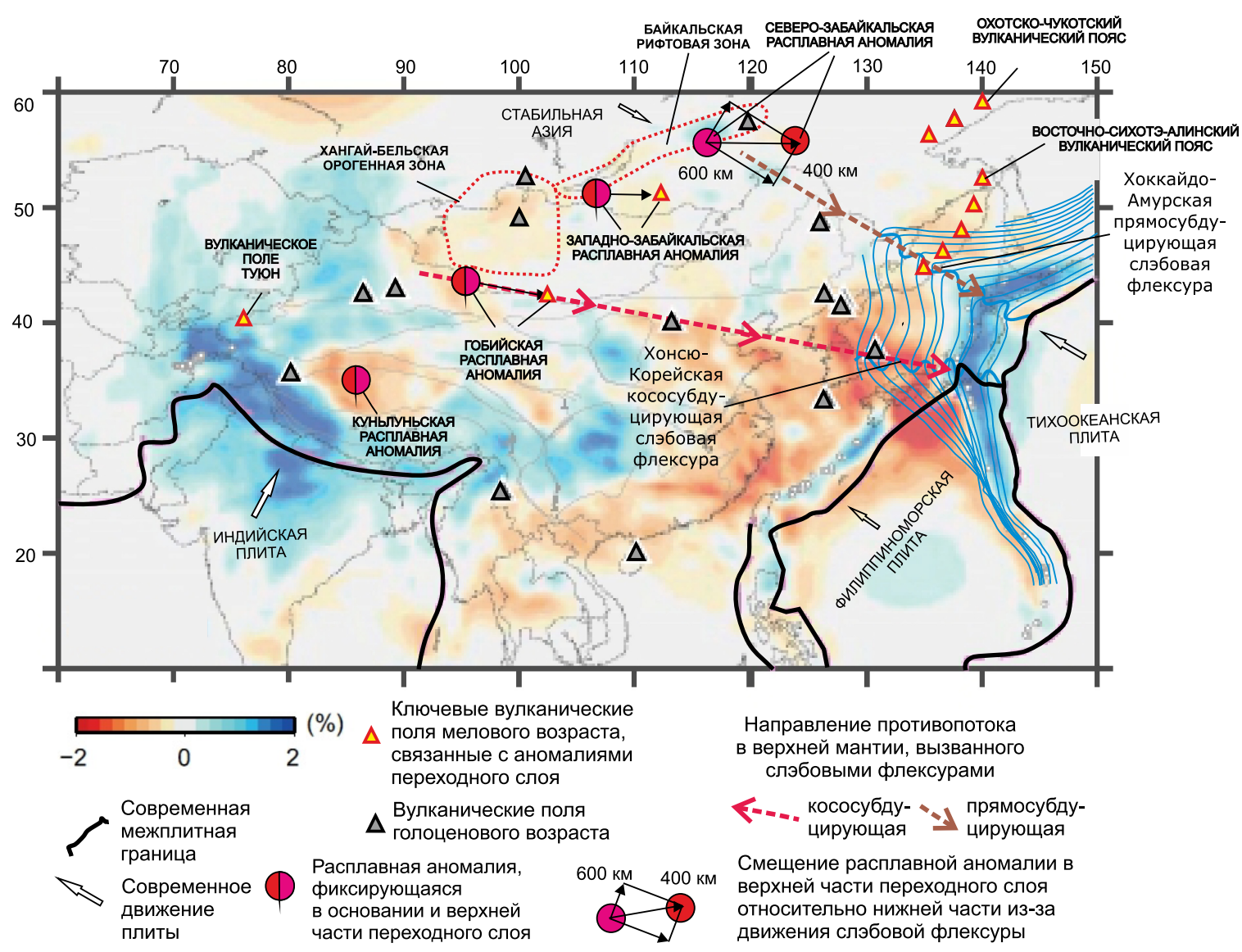

Рис. 14. Пространственные соотношения между выделенными расплавными аномалиями переходного слоя Байкало-Монгольского региона и флексурами субдуцирующего Тихоокеанского слэба.

В дополнение к первичным меловым аномалиям переходного слоя показана Куньлуньская первичная расплавная аномалия переходного слоя, которая соответствует центральной части вулканического ареала последних 18 млн лет, вытянутого в субширотном направлении вдоль террейна Сонгпан-Ганзи на 1200 км. Аномалия выражена в модели скоростей Р-волн [Wei et al., 2012]. В качестве подложки использована карта аномалий глубинного уровня 200 км из этой работы. Усл. обозн. см. рис. 11 и 13.

Fig. 14. Spatial relations between the melting anomalies in the transition layer in the Baikal-Mongolian region and the flexures of the subducted Pacific slab.

In addition to the Cretaceous primary anomalies, the Kunlun primary melting anomaly is distinguished in the transition layer. It corresponds to the central part of the volcanic area stretching from west to east for almost $1200 \mathrm{~km}$ along the Songpan-Ganzi terrane. This volcanic area was active in the last $18 \mathrm{Ma}$. The anomaly is defined in the P-wave velocity model [Wei et al., 2012]. The background of this figure is the map from [Wei et al., 2012], which shows anomalies at the depth of $200 \mathrm{~km}$. See the symbols in Figs 11 and 13.

мантии, т.е. до границы мантии с ядром, до нижней или верхней границы переходного слоя, а также до уровня 200 км верхней мантии. Между тем позднемеловые, палеогеновые и неогеновые вулканические поля могут смещаться от низкоскоростных аномалий, расположенных в верхней мантии, переходном слое или нижней мантии, в связи с движением литосферы. Объединение таких вулканических полей с низкоскоростными мантийными неоднородностями в расплавные аномалии будет зависеть от направления и скорости движения литосферы.

На рис. 15 показаны верхнемантийные низкоскоростные аномалии S-волн. По крайней мере, часть из них образовалась в результате преобразования первичных расплавных аномалий переходного слоя. В настоящей работе мы рассмотрим динамику, обусловившую происхождение СаяноХангайского низкоскоростного домена (глубина 50-200 км) и Северо-Байкальской локальной аномалии (глубина 250-300 км), относящейся к Забайкальскому низкоскоростному домену.

Первичные расплавные аномалии Азии находятся под Центрально-Азиатской орогенной системой (Гобийская), под центральной частью Байкальской рифтовой системы (Западно-Забайкальская), под ее северо-восточной частью и сопредельной Олекмо-Становой орогенной системой (Северо-Забай- 

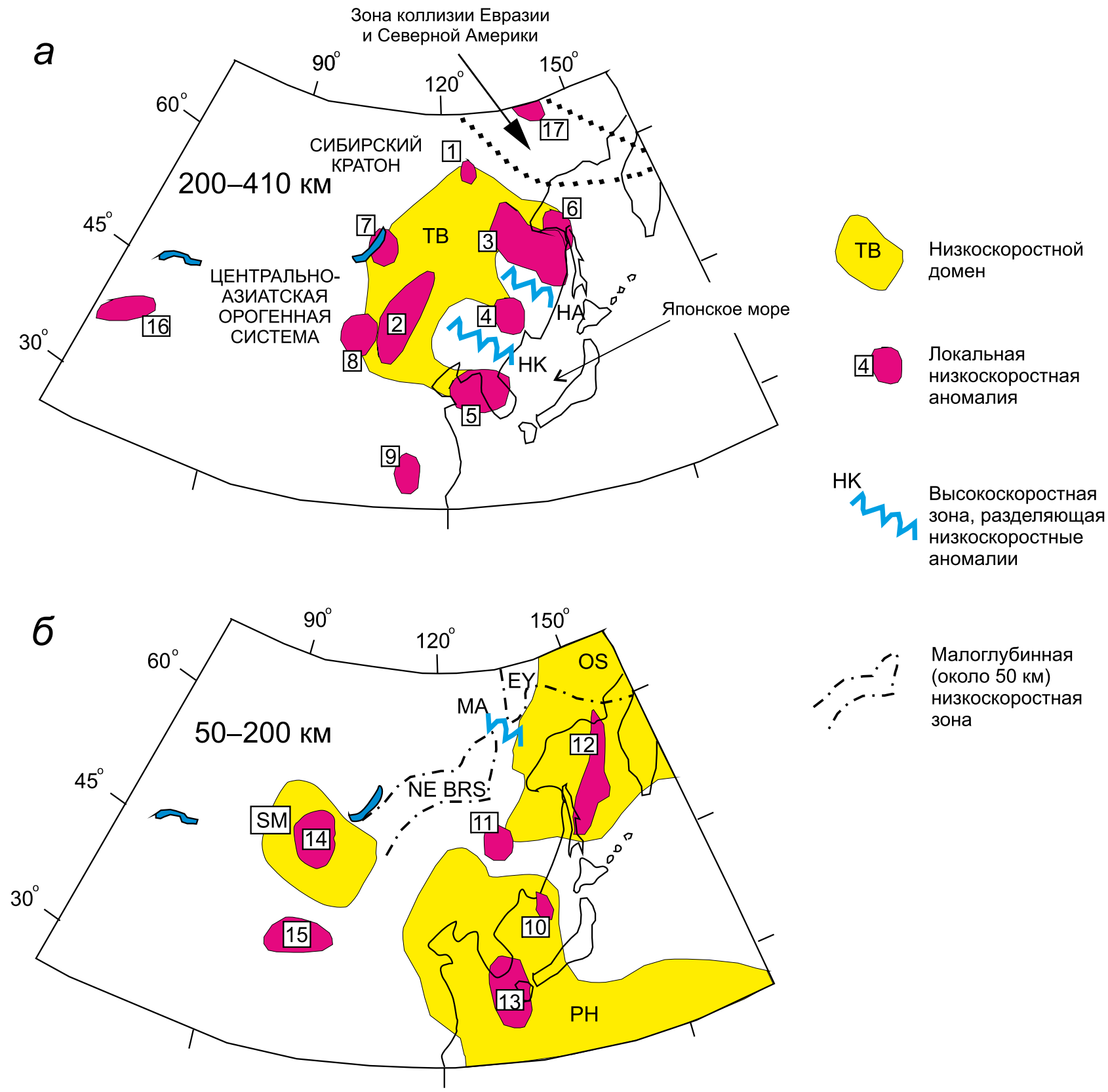

Рис. 15. Аномалии низких скоростей на глубинных ярусах 200-410 км (a) и 50-200 км (б) в Центральной и Восточной Азии.

Низкоскоростные домены: ТВ - Забайкальский, SM - Саяно-Монгольский (Саяно-Хангайский), OS - Oхотоморский, PH - Филиппиноморский. Низкоскоростные локальные аномалии: 1 - Ленская (глубина 300-350 км), 2 - Восточно-Монгольская (250 км), 3 - Совгаванско-Удская (200-250 км), 4 - Амурская (200-250 км), 5 - Северо-Корейская (200-250 км), 6 - Северо-Сахалинская (300 км), 7 - Северо-Байкальская (250-300 км), 8 - Южно-Монгольская (200 км), 9 - Южно-Китайская (300-350 км), 10 - ЮжноПриморская (100 км), 11 - Зейская (100 км), 12 - Сахалино-Магаданский аномальный выступ над Охотоморской линзой (100 км), 13 - Южно-Корейская (200 км), 14 - Северо-Монгольская (150 км), 15 - Цайдамская (100 км), 16 - Таримская (300350 км), 17 - Эльгинская (200 км). Высокоскоростные перемычки: НА - Хоккайдо-Амурская, НК - Хонсю-Хинганская, МА - Среднеалданская. Малоглубинные (50 км) низкоскоростные зоны: NE BRS - северо-восточной части Байкальской рифтовой системы, EY - структур Восточной Якутии. По работе [Rasskazov et al., 2003] с изменениями.

Fig. 15. Low-velocity anomalies within mantle stages of 200-410 km (a) and 50-200 km (b) in East and Central Asia.

Low velocity domains: TB - Transbaikal, SM - Sayan-Mongolia, OS - Okhotsk Sea, PH - Philippine Sea. Local low velocity anomalies: 1 - Lena (depth 300-350 km), 2 - East Mongolia (250 km), 3 - Sovgavan-Uda (200-250 km), 4 - Amur (200-250 km), 5 - North Korea (200-250 km), 6 - North Sakhalin (300 km), 7 - North Baikal (250-300 km), 8 - South Mongolia (200 km), 9 - South China (300-350 km), 10 - South Primorye (100 km), 11 - Zeya (100 km), 12 - Sakhalin-Magadan (above the Okhotsk Sea lens), 13 - South Korea (200 km), 14 North Mongolia (150 km), 15 - Tsaidam (100 km), 16 - Tarim $(300-350$ km), 17 - Elga (200 km). High-velocity dividers: HA - HokkaidoAmur, HK - Honshu-Khingan, MA - Middle Aldan. Shallow (50 km) low velocity zones: NE BRS - Northeastern Baikal Rift System, EY East Yakutia. Modified after Rasskazov et al. [2003]. 
кальская), под Индо-Азиатской коллизионной зоной (Куньлуньская). Первоначально расплавные аномалии этого типа проявили активность и под рифтовыми системами Восточной Азии (Чангбайская и Дариганская), но корневые части переходного слоя этих аномалий были уничтожены слэбами, продвинувшимися по переходному слою (см. рис. 11).

Расплавные аномалии Байкало-Монгольского региона (Гобийская, Западно-Забайкальская и Северо-Забайкальская) относятся к категории слабых, в отличие, например, от Гавайского плюма, представляющего пример сильной расплавной аномалии. Отличие в силе Гавайского плюма от расплавных аномалий Байкало-Монгольского региона выражается в параметрах скорости плавления и максимальной скорости апвеллинга мантийного материала. Для плейстоцен-голоценовых вулканических пород Хангая была получена оценка максимальной скорости апвеллинга материала $\mathrm{W}_{\max }=5.2 \mathrm{cм} \cdot$ год $^{-1}$, а для пород Саян - более высокое значение $-\mathrm{W}_{\max }=11$ см.год ${ }^{-1}$ [Rasskazov et al., 2014]. Эти значения существенно уступают параметру Гавайского мантийного плюма. Скорость плавления М оценивается в Гавайском плюме величинами $<3 \cdot 10^{-4} \kappa г \cdot \mathrm{M}^{3} \cdot$ год $^{-1}$. Из 50 опубликованных определений $230 \mathrm{Th} / 238 \mathrm{U}$, за исключением шести, лавы о-ва Гавайи дали значение, равное 1.0 в пределах $2 \sigma$. Слабый избыток ${ }^{230}$ Th объясняется здесь высокой максимальной скоростью апвеллинга материала мантийного плюма $\mathrm{W}_{\max }=30$ см.год ${ }^{-1}$ и высокой плавучестью (7.4-9.0 $\mathrm{Mg} \mathrm{s}^{-1}$ ] [Beattie, 1993; Turcotte, Schubert, 2014]. Под Гавайями находится низкоскоростная колонна, протягивающаяся до границы ядра [Zhao, 2009]. Несмотря на то, что Тихоокеанская плита движется на запад-северо-запад со скоростью около $10 \mathrm{cм} \cdot г о д^{-1}$, плюм сохраняет прямую конфигурацию низкоскоростной колонны под литосферой Тихоокеанской плиты благодаря динамическому напору, действовавшему в последние 50 млн лет [Tarduno et al., 2009].

Эффект волочения (drag) на границе астеносферы и движущейся литосферы, направленный в Гобийской аномалии субширотно, вдоль простирания Солонкерского и Урало-Монгольского швов закрывшихся фанерозойских палеоокеанов, в ее деформациях не отражается. Обращаясь к Байкальской рифтовой зоне, отметим асимметричность поднятия астеносферы, ее положение под Сибирской платформой «...на гораздо большей глубине, чем под Забайкальской областью умеренного горообразования» [Zorin, 1971, p. 143]. На этом основании делался вывод о том, что «... горизонтальное течение вещества астеносферы должно быть направлено с северо-запада на юго-восток» [Там же]. Такое же течение астеносферы допускалось и в более поздних работах [Gao et al., 1994a, 1994b; Lebedev et al., 2006; Sankov et al., 2011]. Движение литосферы в этих гипотезах, однако, не учитывалось. В развиваемой нами модели растяжение литосферы под Байкальской впадиной определялось динамическим эффектом обратного астеносферного потока в расплавной аномалии переходного слоя.

На рис. 16 показано субширотное сечение Западно-Забайкальской расплавной аномалии переходного слоя. В результате смещения литосферы первичная расплавная аномалия переходного слоя в настоящее время находится почти под Байкалом. Малоглубинный подвижный шлейф протягивается под Западное Забайкалье, а более глубинный обратный поток - под Сибирский кратон. Эффект волочения астеносферы относительно подошвы литосферы Забайкалья обеспечивает растягивающее усилие от Байкальской впадины к востоку, тогда как эффект волочения астеносферы относительно подошвы литосферы Сибирского кратона - растягивающее усилие от Байкальской впадины к западу. Следовательно, литосфера Байкальского рифта находится под воздействием девиаторного (направленного из одной точки в противоположные стороны) течения материала в Западно-Забайкальской расплавной аномалии переходного слоя. Волочение на границе астеносферы и движущейся литосферы направлено от области резкой смены толщины литосферы и приводит к растяжению ее основания, передающемуся на все сечение.

В развитии Западно-Забайкальской расплавной аномалии переходного слоя воспроизводится следующая последовательность событий. Под закрывавшимся Монголо-Охотским заливом Палеопацифика в переходном слое накапливался слэбовый материал, находившийся в стагнации до середины мела. К последнему геодинамическому этапу, начавшемуся около 100-90 млн лет назад, этот материал лавинообразно обрушался из переходного слоя в нижнюю мантию с возникновением обратного горячего потока. Импульс обрушения отразился в вулканизме Хушиндинского поля. Горячий поток способствовал локальному разогреву верхней мантии Западного Забайкалья. Во временном интервале позднего мела, 90-65 млн лет назад, движение литосферы было пренебрежимо малым. Вулканическая деятельность отсутствовала. В конце мела и начале палеогена движение литосферы активизировалось и сопровождалось вулканической деятельностью на Иренгинском поле. В это время на востоке Азии проявился механизм ролбэк, действие которого повторилось в раннем-среднем миоцене, в начале субдукции Тихоокеанского слэба, и выразилось в раскрытии Японского моря. Соответственно, движение литосферы, инициирован- 


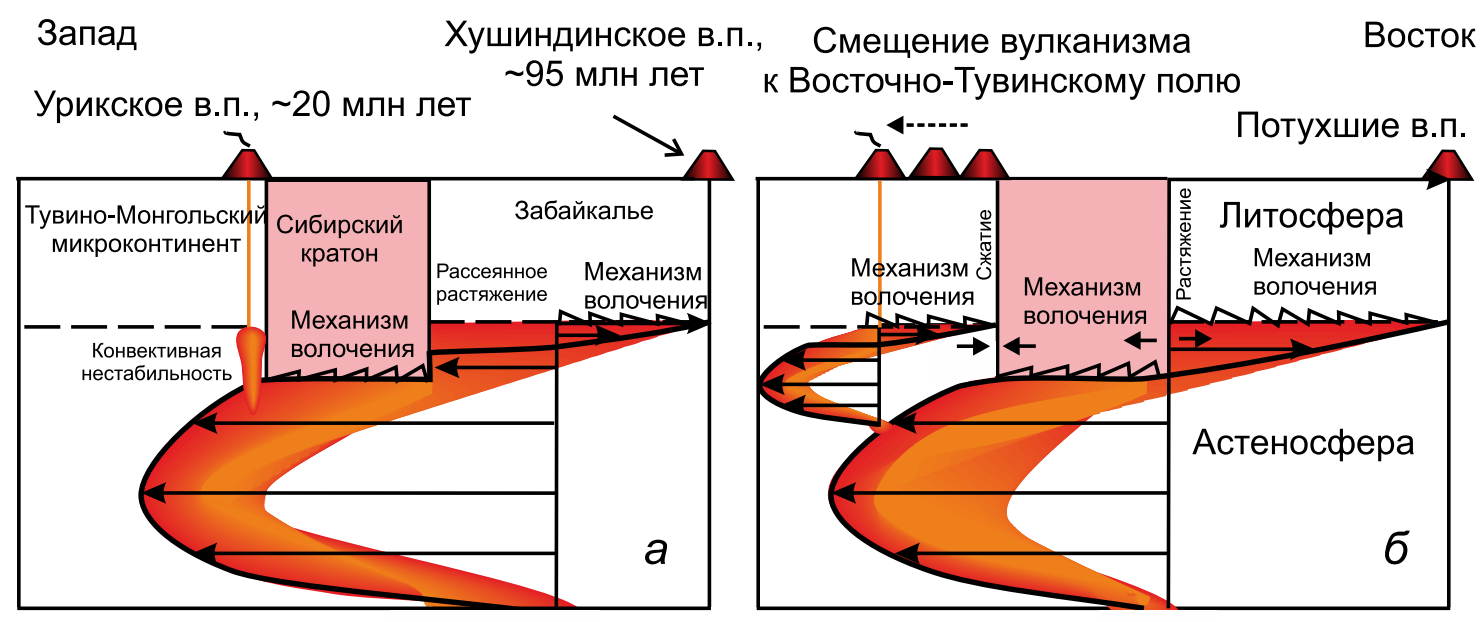

Мезосфера

Рис. 16. Происхождение вторичной Саянской расплавной аномалии.

Малоглубинный обратный поток образовался под движущейся литосферой вследствие конвективной нестабильности в обратном потоке первичной Западно-Забайкальской расплавной аномалии. Нестабильность была создана за килем Сибирского кратона около 20 млн лет назад.

Fig. 16. Origin of the secondary Sayan melting anomaly.

The shallow counterflow under the moving lithosphere was initiated due to convective instability in the counterflow of the primary West Trabsbaikalie melting anomaly. The instability occurred beyond the Siberian craton's keel at about 20 Ma.

ное во временном интервале 65-50 млн лет назад, получило новый импульс 22-15 млн лет назад. Раннесреднемиоценовая структурная перестройка привела к развитию вторичных расплавных аномалий на уровне верхней мантии со смещением вулканизма к западу от Сибирского кратона (в Саянах) и к северо-востоку от первичного Западно-Забайкальского потока переходного слоя (на Витимское плоскогорье).

\section{5. САЯНСКАЯ РАСПЛАВНАЯ АНОМАЛИЯ КАК ПРОИЗВОДНАЯ ЗАПАДНО-ЗАБАЙКАЛЬСКОЙ}

На малых глубинах (50-200 км) под Саянами зарегистрирована низкоскоростная мантия северной части Саяно-Хангайского низкоскоростного домена [Rasskazov et al., 2003]. Обширная область позднекайнозойского вулканизма, пространственно совпадающая с этим доменом, удалена от фрагментов швов закрывшихся фанерозойских палеоокеанов, поэтому действие механизма активизации глубинных процессов в связи с динамикой обрушения слэбового материала из переходного слоя в нижнюю мантию под этой областью маловероятна. По сочетанию структур сжатия (надвигов) и растяжения (сбросов) обстановка этой территории определялась как результат наложения растяжения Байкальской рифтовой системы на область сжатия Центрально-Азиатской орогенной системы [Rasskazov et al., 1998].
Принимая гипотезу растяжения в Байкальской рифтовой зоне за счет девиаторного течения астеносферных потоков первичной Западно-Забайкальской аномалии, мы рассматриваем Саянскую расплавную аномалию как вторичную, образовавшуюся в результате развития первичной Западно-Забайкальской. Обратный поток Западно-Забайкальской расплавной аномалии переходного слоя распространялся под литосферой к западу от мелового Хушиндинского вулканического поля. Эффект волочения астеносферы относительно подошвы движущейся литосферы Забайкалья в общем обеспечивал ее растяжение, рассредоточенное между районами Хушиндинского вулканического поля и Южного Байкала.

С началом раннемиоценового действия механизма ролбэк на востоке Азии проскальзывание обратного астеносферного потока по подошве киля Сибирского кратона вызвало нестабильность малоглубинной (до 200 км) астеносферы у его югозападного края, под сопредельным Тувино-Монгольским микроконтинентом. В саянской части Саяно-Хангайского домена имело место смещение фаз наиболее продуктивного вулканизма в западном направлении от Урикского поля (фаза продуктивного вулканизма около 20 млн лет назад при интервале 20-10 млн лет назад) через Окинское (фаза продуктивного вулканизма 14-10 млн лет назад при интервале 20-2 млн лет назад) к Восточно-Тувинскому (фаза продуктивного вулканизма 
$<2$ млн лет назад при интервале <17 млн лет назад), отразившее динамику малоглубинного обратного потока. Волочение астеносферы относительно подошвы литосферы во вторичной Саянской расплавной аномалии было направлено от Саян к югозападному краю Сибирского кратона - противоположно направлению волочения астеносферы по подошве литосферы Сибирского кратона. Таким образом, в отличие от юго-восточного края кратона, вдоль которого с течением времени концентрировалось растяжение, вдоль его юго-западного края концентрировалось сжатие (рис. 16). Этим объясняется последовательное угасание вулканизма от Урикского поля через Окинское к Восточно-Тувинскому.

\section{6. ХАНГАЙСКАЯ РАСПЛАВНАЯ АНОМАЛИЯ КАК ПРОИЗВОДНАЯ ГОБИЙСКОЙ: СОПОСТАВЛЕНИЕ С КУНЬЛУНЬСКОЙ}

Сейсмические скоростные модели, построенные разными авторами для территории Центральной Монголии [Yanovskaya, Kozhevnikov, 2003; Mordvinova et al., 2007; Chen et al., 2015a, 2015b], свидетельствуют о низких скоростях под Хангаем преимущественно в диапазоне глубин от 40 до 200 км. Нижнемантийное происхождение расплавной аномалии непосредственно под этим горным сооружением сомнительно.

Между тем пространственное смещение вулканизма с юга на север (рис. 17) свидетельствует о наиболее вероятном местоположении первичной расплавной аномалии переходного слоя под Южной Гоби. Пространственно-временное распространение кайнозойского вулканизма на территории Центральной Монголии характеризуется четырьмя ареалами. В интервале 65-43 млн лет назад вулканизм распространился в Средней и Южной Гоби, в интервале 41-21 млн лет назад сместился к западу, а в интервалах 20-10 и менее 10 млн лет - к северу. Мы предполагаем, что мигрировавший вулканизм маркировал процесс образования вторичной расплавной аномалии верхней мантии, распространявшейся от первичного Гобийского горячего потока переходного слоя по механизму малоглубинного потока Куэтта под деформируемой литосферой (рис. 18).

Латеральное субширотное течение астеносферного материала под Гоби имело место в условиях преобладающего субмеридионального сжатия, производного Индо-Азиатского взаимодействия. В отличие от «свободного» восточного континентального края Азии, явившегося причиной движения блоков к востоку по субдукционному сценарию, северный край Азии такого сценария не обеспечивал. Ограниченное продвижение Гобийского литосферного блока к северу относительно сопредель- ных территорий, в связи с низкой вязкостью подлитосферной мантии Гобийской расплавной аномалии, создало условие для усиления тектонического стресса в Хангайском орогене с его деламинацией и соответствующим развитием орогенной расплавной аномалии в подстилающей верхней мантии.

Если Хангайская расплавная аномалия вторична и была производной от первичной Гобийской, то логично предположить, что во вторичной аномалии должен наследоваться характер строения первичной. Из анализа скоростной структуры Гоби следовало, что ее передовая малоглубинная часть, испытавшая волочение по подошве литосферы, охватывала интервал глубин 50-100 км, а более глубинная часть (150-300 км) вовлекалась в обратный поток, отделенный от нее [Rasskazov, Chuvashova, 2016]. Такая конфигурация свидетельствовала об эффективной подвижности верхней мантии на глубине 50-100 км. Поток Куэтта, маркированный мигрировавшим вулканизмом, унаследовал малоглубинную часть обратного потока Гоби, сопряженную с волочением подошвы литосферы в расплавной аномалии. С 65 до 21 млн лет назад (в основном до 31 млн лет назад) пространственное распределение вулканизма в Южной и Средней Гоби маркировало эффект сочетания динамики обратного потока первичной Гобийской расплавной аномалии и динамики зарождавшегося потока Куэтта. В последние 17 млн лет поток Куэтта распространился к северу при потере связи с первичной Гобийской аномалией и приобрел самостоятельное значение вторичной аномалии, в которой рост Хангайского орогена сочетался с растяжением в Центрально-Монгольском рифтовом сегменте.

В целом мы видим, что результирующий востокюго-восточный вектор смещения литосферы с мелпалеогеновыми вулканическими полями относительно первичной Гобийской низкоскоростной аномалии переходного слоя был обусловлен в основном общим движением литосферы Азии. Небольшой северный дрейф создавался Индо-Азиатской конвергенцией. Позднекайнозойский вулканизм Хангай-Бельской орогенной зоны был производным расплавных аномалий малых глубин мантии (50-150 км) Саяно-Хангайского низкоскоростного домена. Низкоскоростные аномалии СаяноХангайского низкоскоростного домена (150-200 км) и подстилающей верхней мантии со слэбовыми фрагментами (300 км) смещены к западу относительно первичной расплавной аномалии переходного слоя, зафиксированной в модели В.М. Кожевникова, и других низкоскоростных аномалий на глубинах 400 и 100 км. Результирующий восток-юго-восточный вектор движения литосферы относительно этих низкоскоростных аномалий 


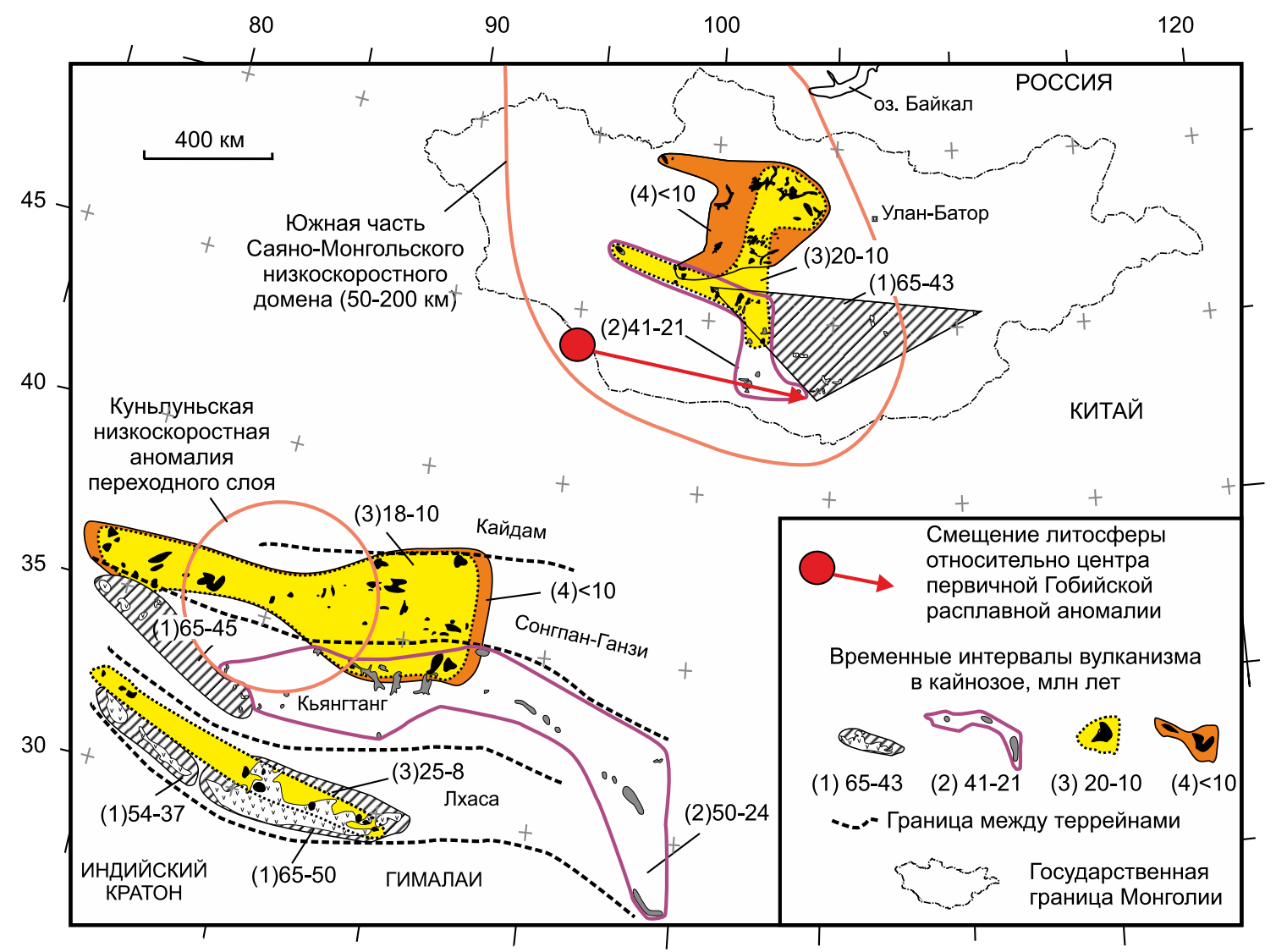

Рис. 17. Пространственно-временное смещение кайнозойских вулканических ареалов в Центральной Монголии в результате преобразования первичной Гобийской расплавной аномалии с последовательным северным распространением вторичной Хангайской.

Для сопоставления показано пространственно-временное смещение одновозрастного вулканизма Тибета. Контур южной части Саяно-Монгольского (Саяно-Хангайского) низкоскоростного домена показан по работе [Rasskazov et al., 2003], контур Куньлуньской низкоскоростной аномалии переходного слоя выделен по модели [Wei et al., 2012].

Fig. 17. Spatial-temporal shift of the Cenozoic volcanic areals in Central Mongolia, which resulted from the transformation of the primary Gobi melting anomaly, followed by the gradual northward propagation of the secondary Hangay melting anomaly.

For comparison, the Cenozoic volcanic evolution in Tibetan Plateau is shown. The southern circuit of the Sayan-Mongolian low-velocity domain is shown after Rasskazov et al. [2003]. The contour of the Kunlun low-velocity anomaly in the transition layer is shown according to the model of Wei et al. [2012].

совпадал с вектором движения литосферы в Южной Гоби с сокращением амплитуды до 300 км. Средняя скорость движения литосферы за 15 млн лет составила 2 см.год ${ }^{-1}$. Допуская такую же скорость движения литосферы Южной Гоби в последние 15 млн лет, получаем оценку средней скорости движения литосферы Центральной Монголии в предшествующий интервал с 90 до 15 млн лет назад около $0.4 \mathrm{~cm} \cdot$ год $^{-1}$.

В Тибете выделяются временные интервалы пространственного перераспределения вулканизма, подобные интервалам Центральной Монголии. Особенно обращает на себя внимание синхронное продвижение вулканизма Центральной Монголии и Тибета к северу в последние 20 млн лет. Ареалы тибетского вулканизма 18-10 и <10 млн лет назад совпадали между собой и, по-видимому, подпитывались в центральной части мантийным потоком, обозначенным Куньлуньской низкоскоростной аномалией. Расплавная аномалия протягивается здесь из верхней части нижней мантии через переходный слой и верхнюю мантию и по этим признакам должна рассматриваться как первичная. В течение последних 18 млн лет эта аномалия в мантии зоны Индо-Азиатской конвергенции была фиксирована.

На субмеридиональном скоростном профиле через Центральный Тибет переход от литосферы к астеносфере зарегистрирован в глубинном интервале 160-225 км [Mechie et al., 2010]. Эти оценки 
I.S. Chuvashova et al.: The latest geodynamics in Central Asia...
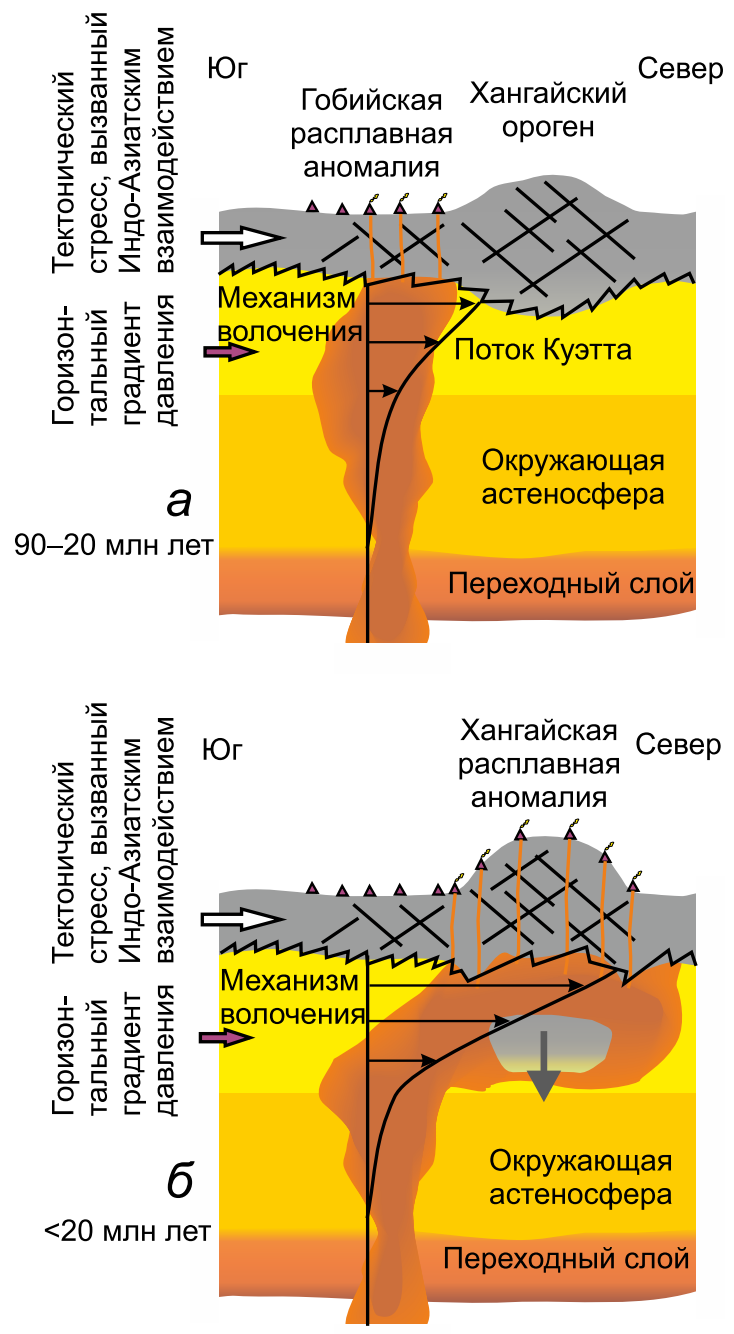

Рис. 18. Облегчение передачи сжатия от Индо-Азиатской зоны конвергентного взаимодействия к Хангайскому орогену с образованием малоглубинного потока Куэтта в низковязкостной мантии первичной Гобийской расплавной аномалии $(a)$ и последующие малоглубинные мантийные процессы деламинации утолщенной корневой части орогена (б). Из работы [Rasskazov, Chuvashova, 2016] с дополнениями.

Fig. 18. Facilitation of the tectonic stress transfer from the Indo-Asian zone of convergent interaction to the Hangay orogen due to formation of the Couette shallow flow in the low-viscosity mantle at the Gobi melting anomaly $(a)$ and the subsequent delamination of the thickened orogen root in the shallow mantle (б). Modified after [Rasskazov, Chuvashova, 2016].

согласуются с моделью сейсмической томографии Р-волн [Wei et al., 2012], свидетельствующей об общем снижении скоростей в верхней мантии под Тибетом на глубинах более 200 км. Подобные оценки глубины границы литосферы-астеносферы под Центральной Монголией [Chen et al., 2015a], однако, не согласуются с другими сейсмическими скоростными моделями и характером смещений низкоскоростных аномалий под движущейся литосферой с образованием обратного субширотного потока и субмеридионального потока Куэтта на малых глубинах (до 50 км).

\section{7. ВИТИМСКАЯ РАСПЛАВНАЯ АНОМАЛИЯ КАК ПРОИЗВОДНАЯ ЗАПАДНО-ЗАБАЙКАЛЬСКОЙ}

Подобно кайнозойскому вулканизму Центральной Монголии, кайнозойский вулканизм Западного Забайкалья смещался в северном направлении, от Хушиндинского и Иренгинского вулканических полей к Витимскому. По аналогии с Центральной Монголией, в Западном Забайкалье вулканизм маркировал процесс образования вторичной расплавной аномалии верхней мантии, распространявшейся к северу от первичной Западно-Забайкальской расплавной аномалии переходного слоя по механизму потока Куэтта.

Северо-Байкальская локальная область низких скоростей - корневая часть вторичной Витимской расплавной аномалии - находится на 100-200 км глубже низкоскоростных аномалий Центральной Монголии, принадлежащих Саяно-Хангайскому домену. В отличие от Центральной Монголии, литосфера Витимского плоскогорья не подвергалась субмеридиональному латеральному сжатию, a, наоборот, испытывала транстенсию, выраженную в образовании правосторонних кулис в субмеридиональном Ципа-Муяканском сегменте впадин Байкальской рифтовой зоны. Более глубокое движение астеносферного потока Куэтта реализовалось в условиях транстенсии литосферы этой территории.

Во впадинах южной (еравнинской) части ЦипаМуяканского транстенсионного сегмента осадки накапливались до олигоцена включительно, а во впадинах северной (муяканской) части, в Чарской и других впадинах северо-востока Байкальской рифтовой зоны - с середины миоцена. В результате продвижения потока Куэтта центр вторичной расплавной аномалии оказался под Витимским вулканическим полем к северу от трассы первичной аномалии переходного слоя. Это вторичное боковое локальное расплавное обособление не вовлекалось в обратное движение астеносферы относительно первичной аномалии в переходном слое, поэтому вместе с первичной Западно-Забайкальской аномалией служит в качестве репера регистрации восток-юго-восточного движения литосферы.

Начальные высоко-Mg извержения Витимского вулканического поля в Береинском центре 16-14 млн лет назад свидетельствовали о позднекайнозойском локальном импульсном адиабатическом поднятии горячего потока в верхней мантии 
[Chuvashova et al., 2016]. При движении литосферы приблизительно с 15 млн лет назад до настоящего времени Береинский вулканический центр сместился на 300 км к востоку относительно центра Северо-Байкальской низкоскоростной аномалии, расположенной на глубине 250-300 км. Это смещение дает среднюю оценку позднекайнозойской скорости движения литосферы порядка 2 см.год -1 , приближающуюся к скорости современного движения Стабильной Азии.

Принимая амплитуду смещения Западного Забайкалья на 300 км за последние 15 млн лет для Иренгинского поля, мы должны ограничить путь движения этой территории временным интервалом 15 млн лет и объяснять небольшое (50 км) смещение вулканизма от Хушиндинского поля к Иренгинскому однонаправленным движением литосферы. Оценка средней скорости этого движения, отнесенная к временному интервалу 100-50 млн лет назад, составляет небольшую величину (около $0.1 \mathrm{cм} \cdot$ год $^{-1}$ ).

\section{8. ЯПОНСКО-БАЙКАЛЬСКИЙ ГЕОДИНАМИЧЕСКИЙ КОРИДОР И ЕГО ЛАТЕРАЛЬНЫЕ ОГРАНИЧЕНИЯ}

По направлениям и характеру смещений мантийного материала под движущейся литосферой в Азии различаются три мантийные геодинамические области: (1) северо-восточная с деформациями, охватившими переходный слой во фронте Хоккайдо-Амурской слэбовой флексуры, (2) центральная, ограниченная верхней мантией и динамически связанная с механизмом ролбэк, проявившимся в образовании Хонсю-Корейской слэбовой флексуры и подобной флексуры раннего кайнозоя, и (3) юговосточная, включающая территорию Юго-Восточной Азии, расположенную восточнее и юго-восточнее Индийского индентора (рис. 19). Первые две области образуют Японско-Байкальский геодинамический коридор. В последней области геодинамика, по-видимому, определялась южным движением литосферных блоков [Jolivet et al., 1994; Rasskazov et al., 1998]. В настоящей работе эта геодинамическая область не рассматривается.

Японско-Байкальский коридор астеносферных потоков ограничен по латерали на северо-востоке и юго-западе областями субвертикально-стагнирующих меловых слэбов, пространственно связанных с зонами Индо-Азиатского и Америко-Азиатского взаимодействия.

Под Южным и Срединным Тянь-Шанем высокими скоростями обозначены две совокупности палеослэбовых фрагментов, погружающихся навстречу друг другу и стагнирующих в верхней мантии и переходном слое (рис. 20). В верхней части разреза ширина зоны слэбов составляет около 400 км. На глубине 300 км ширина уменьшается до 250 км. Палеослэбовые стагнирующие фрагменты под Тянь-Шанем интерпретируются как фрагменты литосферы закрывшегося Туркестанского палеоокеана. Частично высокоскоростной материал может представлять собой также фрагменты деламинированного киля позднекайнозойского ТяньШаньского орогена. Относительное снижение скоростей под Тянь-Шанем наблюдается в виде клина, заключенного над высокоскоростными слэбовыми фрагментами выше переходного слоя мантии. Наиболее низкие скорости определены на глубинах менее 90 км. В конфигурации высокоскоростных и низкоскоростных фрагментов явно отражается раздел 410 км. Между тем даже по этому разделу субмеридиональное латеральное смещение мантийного материала со времени закрытия Туркестанского палеоокеана было ничтожным. По этому направлению могли происходить смещения на большей глубине. Не исключено, что имели место субширотные смещения мантийного материала. В любом случае на профиле отсутствуют латеральные движения низкоскоростного верхнемантийного материала, характерные для ЯпонскоБайкальского геодинамического коридора.

Подобный палеослэб стагнировал с позднего мела до настоящего времени без существенных преобразований латеральным движением материала верхней мантии и переходного слоя под северозападной частью Охотского моря и Охотско-Чукотским вулканоплутоническим поясом (рис. 21). Образование этого палеослэба связывается со среднепозднемеловой субдукцией под Азию плиты Кула-Изанаги и консервацией вследствие аккреции к Азии Охотоморского террейна. Отметим, что, в отличие от палеослэба Охотско-Чукотского пояса, палеослэб позднемелового Восточно-Сихотэ-Алинского вулканоплутонического пояса был переработан активными процессами, выраженными в вулканизме внутриплитного типа, продолжавшемся в Восточном Сихотэ-Алине в течение всего кайнозоя и связанном с новейшей субдукцией океанической коры Пацифика.

Палеослэбы Туркестанского палеоокеана и Охотско-Чукотского вулканоплутонического пояса, стагнирующие в верхней мантии и переходном слое до настоящего времени, свидетельствуют о северо-восточном и юго-западном латеральных ограничениях Японско-Байкальского коридора астеносферных потоков, обусловленного конвергенцией Тихоокеанской плиты и Восточной Азии. Этот коридор активных динамических процессов сдерживается на северо-востоке зоной Америко-Азиатского и на юго-западе - зоной Индо-Азиатского взаимодействия, но расширяется на юго-востоке за счет свободного экструзивного движения блоков 


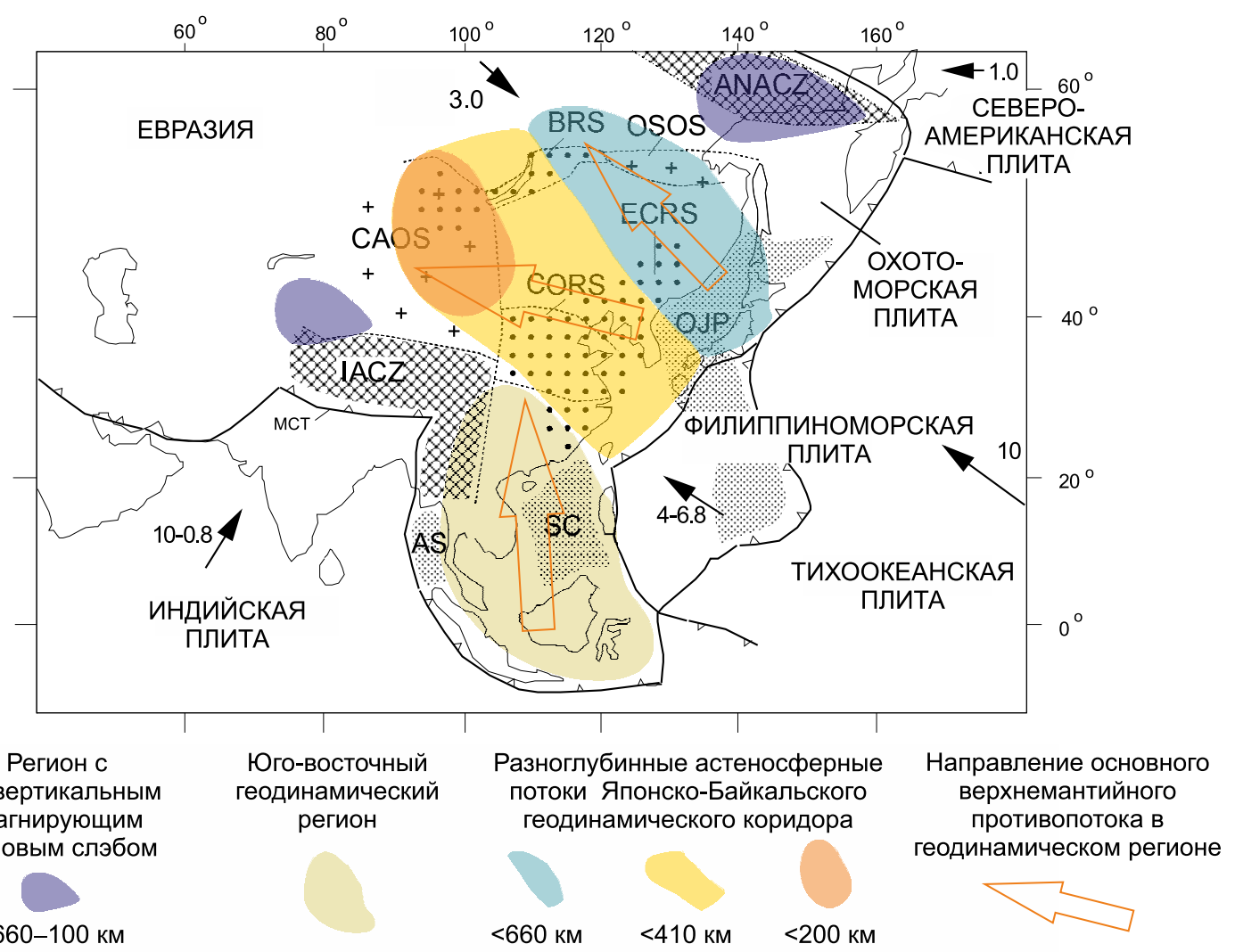

Рис. 19. Соотношения мантийных геодинамических областей с позднекайнозойскими подвижными системами юго-восточной части Евразии.

Карта-схема показывает латеральные ограничения Японско-Байкальского коридора астеносферных потоков зонами ИндоАзиатского и Америко-Азиатского взаимодействия. Направление главного верхнемантийного противопотока в юго-восточном геодинамическом регионе показано предположительно исходя из южного направления движения его литосферных блоков. Усл. обозн. к схеме позднекайнозойских подвижных систем см. на рис. 11.

Fig. 19. Relationships between the mantle geodynamic regions and Late Cenozoic mobile systems in the Southeastern Eurasia.

The sketch map shows that the Japan-Baikal corridor of the asthenospheric flows is limited by the Indo-Asian and American-Asian interaction zones. The direction of the main upper-mantle counterflow in the southeastern geodynamic region is assumed from the southward motion of its lithospheric blocks. Explanations to the scheme of the Late Cenozoic mobile systems are given in Fig. 11.

Индокитая и Южно-Китайского моря. В зоне ИндоАзиатского взаимодействия не только создаются условия стагнации слэбов, но и пространственно фиксируются восходящие мантийные потоки, что видно на примере Куньлуньской расплавной аномалии.

Палеослэбы, стагнирующие в верхней мантии (рис. 20, 21), свидетельствуют о том, что астеносферный слой не имеет сплошного распространения в континентальной верхней мантии, а низкоскоростные неоднородности находятся на ее разных уровнях. В отличие от океанических плит, континенты перемещаются относительно ядра Земли в основном по границе между верхней и нижней мантией.

В целом движения литосферных плит подчиняются двум мантийным ярусам: астеносферному (верхнемантийному) и переходной зоны между верхней и нижней мантией. Пока движутся океанические плиты, они перемещаются относительно друг друга и относительно континентов по астеносферному верхнемантийному слою. В случае закрытия палеоокеана и объединения верхнемантийных областей континентов астеносферные верхнемантийные области консервируются и в дальнейшем могут возобновлять «внутриплитную» магматическую активность по «пассивному» механизму, т.е. вследствие латерального распространения во внутреннюю часть континента процессов межплитной конвергенции. Существует вероятность возобновления «внутриплитной» магматической активности по «активному» механизму, т.е. вследствие поднятия горячего мантийного материала. 


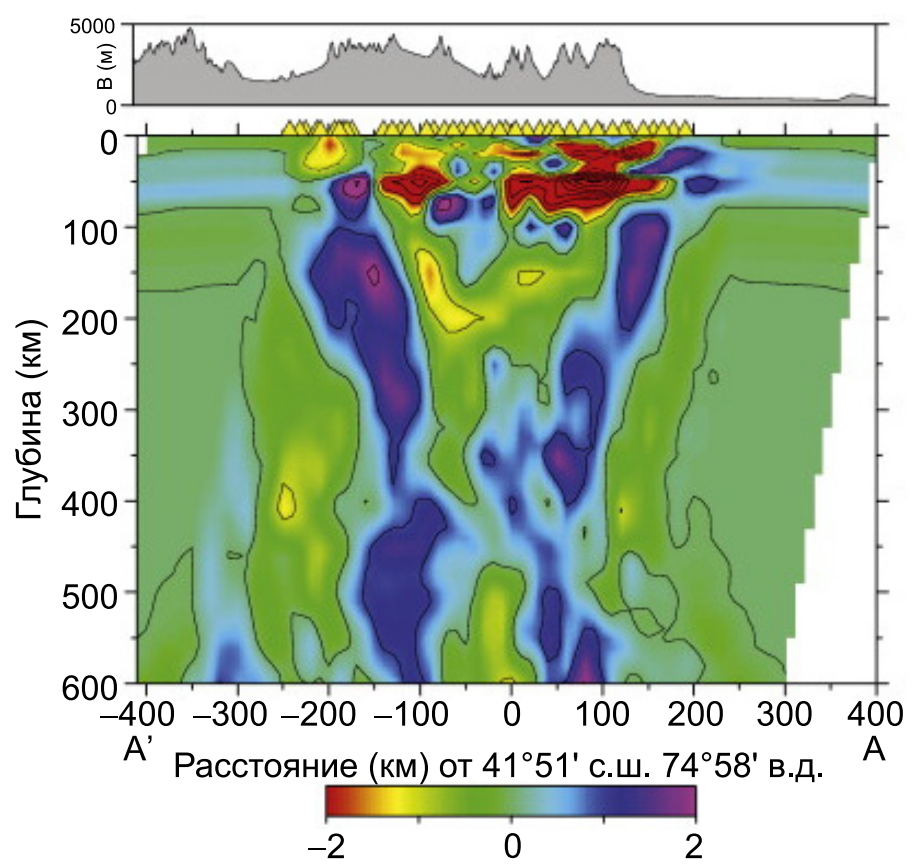

Рис. 20. Отклонения скоростей Р-волн $\left(d V_{\mathrm{P}} / \mathrm{V}_{\mathrm{P}}\right)$ от средней базовой модели, определенные по инверсии телесейсмических неувязок их временного пробега от дальних землетрясений вдоль субмеридионального профиля MANAS, Тянь-Шань [Li et al., 2009].

В нижней части рисунка приведена шкала отклонения скорости в процентах цветовой палитры ( $\pm 2 \%)$. Желтыми треугольниками на земной поверхности показаны станции профиля. В верхней части рисунка показан рельеф Тянь-Шаня вдоль линии разреза, от Киргизского хребта на севере до Таримского блока на юге. Профиль пересекает Тянь-Шань в направлении с севера (A') на юг (A) от $74.5^{\circ}$ до $76.0^{\circ}$ с отметками расстояния от точки (0 км) с координатами: $41.51^{\circ}$ с.ш., $74.58^{\circ}$ в.д.

Fig. 20. Deviations of $P$-wave velocities $\left(d V_{P} / V_{P}\right)$ from the average basic model. The deviation values are defined by inversion of teleseismic inconsistencies of the P-wave travel time from distant earthquakes along the MANAS submeridional profile in Tien Shan [Li et al., 2009].

The scale at the bottom of the figure shows the P-wave velocity deviation range in percentage values of the colour palette $( \pm 2 \%)$. Yellow triangles show locations of the stations along the profile. At the top of the figure, the Tien Shan relief is shown along the cross-section line, from the Kyrgyz ridge in the north to the Tarim block in the south. The profile crosses the Tien Shan from the north $\left(A^{\prime}\right)$ to the south $(A)$ from $74.5^{\circ}$ to $76.0^{\circ}$.The distances are marked from the reference point $(0 \mathrm{~km}): 41.51 \mathrm{~N}, 74.58 \mathrm{E}$.

\section{7.ЗАКЛЮЧЕНИЕ}

Из синтеза данных о вулканической эволюции, движении литосферы и скоростях сейсмических волн в мантии Байкало-Монгольского региона создана обобщающая модель глубинной динамики Азии, в которой важнейшую роль играли первичные Гобийская, Западно-Забайкальская и Северо-
Забайкальская расплавные аномалии переходного слоя. Переходный слой нарушался нижнемантийными потоками в начале новейшего геодинамического этапа (т.е. около 90 млн лет назад) из-за лавинного обрушения слэбового материала, который накопился и стагнировал под закрывшимися фрагментами Солонкерского, Урало-Монгольского палеоокеанов и Монголо-Охотского залива Палеопацифика.

На новейшем геодинамическом этапе Азия была вовлечена в восток-юго-восточное движение при смещении плит Тихого океана в противоположном направлении с субдукцией под окраину Азии. Ослабленная верхнемантийная область Гобийской расплавной аномалии обеспечивала течение об-

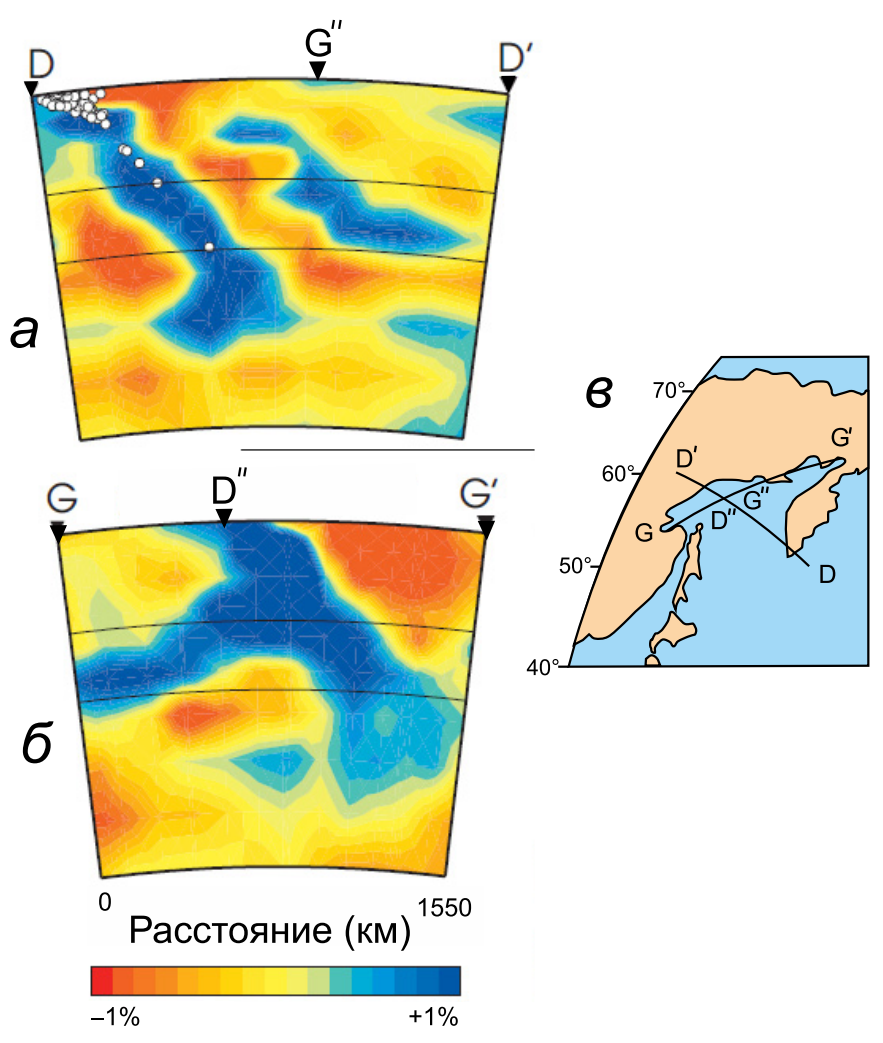

Рис. 21. Разрезы скоростных аномалий DD' (a) и GG' (б) вдоль профилей, пересекающих Охотское море ( 8 ).

Красный и синий цвет обозначает аномалии медленных и быстрых скоростей, соответственно, со шкалой в процентах по отношению к эталонной модели [Gorbatov et al., 2000]. Кружками обозначены эпицентры землетрясений с магнитудой 5.5 и более.

Fig. 21. Cross-sections of the velocity anomalies DD' $(a)$ andGG' (б) along the profiles across at the Okhotsk Sea region $(B)$.

Colour codes: red - low P-wave velocity anomaly, blue - high Pwave velocity anomaly. The scale is in percentage values relative to the reference model described in [Gorbatov et al., 2000]. Open circles show hypocenters of $\mathrm{M} \geq 5.5$ earthquakes. 
ратного потока с проявлением механизма ролбэк в районе Японского моря в палеоцене и раннемсреднем миоцене. Эта динамика отразилась в образовании Хонсю-Корейской флексуры Тихоокеанского слэба. Подобная ослабленная область СевероЗабайкальской расплавной аномалии была сопряжена с образованием Хоккайдо-Амурской флексуры Тихоокеанского слэба, сформировавшейся в результате прогрессирующего затягивания слэбового материала в переходный слой по направлению конвергенции Тихоокеанской плиты и Восточной Азии.

Мы предполагаем, что первичные расплавные аномалии Байкало-Монгольского региона явились главным фактором новейшей активизации территории. Процессы раннесреднемиоценовой структурной перестройки в зоне взаимодействия плит Тихого океана и Восточной Азии и сопряженные процессы в зоне Индо-Азиатского взаимодействия повлекли за собой преобразование первичных расплавных аномалий переходного слоя с оформлением вторичных верхнемантийных, сопровождавшихся развитием орогенеза и рифтогенеза в литосфере. Растяжение Байкальского рифта было обусловлено девиаторным течением мантийного материала, инициированным под движущейся литосферой в первичной Западно-Забайкальской расплавной аномалии переходного слоя. Сжатие в Хангайском орогене создавалось благодаря облегчению передачи этому орогену тектонического стресса от зоны Индо-Азиатского взаимодействия по низковязкой мантии первичной Гобийской расплавной аномалии одновременно с продвижением материала подлитосферной мантии с образованием в последние 20 млн лет вторичной малоглубинной Хангайской расплавной аномалии потоком Куэтта благодаря градиенту давления в ней из зоны Индо-Азиатского взаимодействия. Одновременно обратным потоком Западно-Забайкальской расплавной аномалии создавалась конвективная нестабильность за литосферным килем Сибирского кратона с образованием вторичной малоглубинной Саянской расплавной аномалии. Сочетание динамики вторичных Хангайской и Саянской расплавных аномалий выразилось в низких сейсмических скоростях малоглубинного (50-200 км) Саяно-Хангайского низкоскоростного домена. Вторичная Витимская расплавная аномалия образовалась в позднем кайнозое в результате северного продвижения потока Куэтта от первичной Западно-Забайкальской аномалии.

Японско-Байкальский коридор астеносферных потоков сдерживался на северо-востоке зоной взаимодействия Северной Америки и Азии и на югозападе - зоной взаимодействия Индостана и Азии. Динамика первичных и вторичных расплавных аномалий Байкало-Монгольского региона была ограничена по латерали сопредельными с этими зонами областями позднефанерозойской консервации палеослэбов Туркестанского палеоокеана и Охотско-Чукотского пояса с соответствующей фиксацией пространственного положения восходящих мантийных потоков.

Рассмотренные пространственные соотношения низкоскоростных аномалий переходного слоя с верхнемантийными низкоскоростными аномалиями и их соответствующая связь с вулканизмом позднего мела - раннего-среднего кайнозоя и позднего кайнозоя в Байкало-Монгольском регионе дают представление о закономерностях новейшей глубинной динамики, свойственных этой территории. Для создания завершенной геодинамической модели всей территории Азии выявленные закономерности расплавных аномалий Байкало-Монгольского региона должны тестироваться на расплавных аномалиях Восточной Азии.

\section{8. БЛАГОДАРНОСТИ}

Работа подготовлена в Китайско-Российском исследовательском центре Удаляньчи-Байкал по новейшему вулканизму и окружающей среде, грант № P162011012 и грант научно-исследовательского фонда Академии наук провинции Хэйлуцзян КНР (2016 г.), при частичном финансировании РФФИ, грант 17-05-00614. Авторы благодарят А.Б. Перепелова и В.А. Санькова за конструктивное обсуждение содержания работы.

\section{9. ЛИTEPATYPA / REFERENCES}

Akinin V.V., 2012. Late Mesozoic and Cenozoic magmatism and reformation of the lower crust in the North Pacific framing. Abstract of the thesis. IGEM, Moscow, 43 p. (in Russian) [Акинин В.В. Позднемезозойский и кайнозойский магматизм и преобразование нижней коры в северном обрамлении Пацифики: Автореф. дис. ... докт. геол.-мин. наук. М.: ИГЕМ РАН, 2012. 43 с.].

Anderson D.L., 1995. Lithosphere, asthenosphere, and perisphere. Reviews of Geophysics 33 (1), 125-149. https://doi. org/10.1029/94RG02785.

Anderson D.L., 2007. New theory of the Earth. Cambridge University Press, Cambridge, 384 p. 
Anderson D.L., Tanimoto T., Zhang Y-S., 1992. Plate tectonics and hotspots: the third dimension. Science 256 (5064), 1645-1651. https://doi.org/10.1126/science.256.5064.1645.

Arndt N., Lesher C.M., Barnes S.J., 2008. Komatiite. Cambridge University Press, Cambridge, 458 p.

Beattie P., 1993. Uranium-thorium disequilibria and partitioning on melting of garnet peridotite. Nature 363 (6424), 63-65. https://doi.org/10.1038/363063a0.

Belichenko V.G., Boos R.G., 1990. The problem of distinguishing the early Precambrian in the Central Asia belt of Paleozoic structures. Geologiya i Geofizika (Russian Geology and Geophysics) (11), 3-9 (in Russian) [Беличенко В.Г., Боос Р.Г. Проблема выделения раннего докембрия в Центрально-Азиатском поясе палеозоид // Геология $u$ геофизика. 1990. № 11. С. 3-9].

Belyi V.F., Belaya B.V., 1998. The Late Stage of the Okhotsk-Chukchi Volcanogenic Belt Development (the Enmyvaam River Upper Run Area). NEISRI FEB RAS, Magadan, 108 p. (in Russian) [Белый В.Ф., Белая Б.В. Поздняя стадия развития Охотско-Чукотского вулканогенного пояса (верхнее течение р. Энмываам). Магадан: СВКНИИ ДВО РАН, 1998. 108 с.]

Bercovici D., Karato S., 2003. Whole mantle convection and transition-zone water filter. Nature 425 (6953), 39-44. https://doi.org/10.1038/nature01918.

Bijwaard H., Spakman W., Engdahl E.R., 1998. Closing the gap between regional and global travel time tomography. Journal of Geophysical Research: Solid Earth 103 (B12), 30055-30078. https://doi.org/10.1029/98JB02467.

Calais E., Dong L., Wang M., Shen Z., Vergnolle M., 2006. Continental deformation in Asia from a combined GPS solution. Geophysical Research Letters 33 (24), L24319. https://doi.org/10.1029/2006GL028433.

Calais E., Vergnolle M., San'kov V., Lukhnev A., Miroshnitchenko A., Amarjargal S., Déverchère J., 2003. GPS measurements of crustal deformation in the Baikal-Mongolia area (1994-2002): Implications for current kinematics of Asia. Journal of Geophysical Research: Solid Earth 108 (B10), 2501. http://doi.org/10.1029/2002JB002373.

Castillo P., 1988. The Dupal anomaly as a trace of the upwelling lower mantle. Nature 336 (6200), 667-670. https:// doi.org/10.1038/336667a0.

Chen M., Niu F., Liu Q., Tromp J., 2015a. Mantle-driven uplift of Hangai Dome: New seismic constraints from adjoint tomography. Geophysical Research Letters 42 (17), 6967-6974. https://doi.org/10.1002/2015GL065018.

Chen M., Niu F., Liu Q., Tromp J., Zheng X., 2015b. Multiparameter adjoint tomography of the crust and upper mantle beneath East Asia: 1. Model construction and comparisons. Journal of Geophysical Research: Solid Earth 120 (3), 1762-1786. https://doi.org/10.1002/2014JB011638.

Chuvashova I., Rasskazov S., Yasnygina T., 2016. Mid-Miocene thermal impact on the lithosphere by sub-lithospheric convective mantle material: Transition from high- to moderate-Mg magmatism beneath Vitim Plateau, Siberia. Geoscience Frontiers (in press). https://doi.org/10.1016/j.gsf.2016.05.011.

Condie K.C., 2001. Mantle Plumes and Their Record in Earth History. Cambridge University Press, Cambridge, 246 p.

Courtillot V., Olson P., 2007. Mantle plumes link magnetic superchrons to Phanerozoic mass depletion events. Earth and Planetary Science Letters 260 (3-4), 495-504. https://doi.org/10.1016/j.epsl.2007.06.003.

DeMets C., Gordon R.G., Argus D.F., Stein S., 1990. Current plate motions. Geophysical Journal International 101 (2), 425-478. https://doi.org/10.1111/j.1365-246X.1990.tb06579.x.

DeMets C., Gordon R.G., Argus D.F., Stein S., 1994. Effect of recent revisions to the geomagnetic reversal time-scale on estimates of current plate motions. Geophysical Research Letters 21 (20), 2191-2194. https://doi.org/10.1029/ 94GL02118.

Duncan R.A., Petersen N., Hargraves R.B., 1972. Mantle plumes, movement of European plate and polar wandering. Nature 239 (5367), 82-86. https://doi.org/10.1038/239082a0.

Engebretson D.C., Cox A., Gordon R.G., 1984. Relative motion between oceanic plates of the Pacific basin. Journal of Geophysical Research: Solid Earth 89 (B12), 10291-10310. https://doi.org/10.1029/JB089iB12p10291.

Engebretson D.C., Cox A., Gordon R.G., 1985. Relative motions between oceanic and continental plates in the Pacific basin. Geological Society of America Special Papers, vol. 206, p. 1-60. https://doi.org/10.1130/SPE206-p1.

England P., Molnar P., 1997. Active deformation of Asia: from kinematics to dynamics. Science 278 (5338), 647-650. https://doi.org/10.1126/science.278.5338.647.

Forsyth D., Uyeda S., 1975. On the relative importance of the driving forces of plate motion. Geophysical Journal International 43(1), 163-200. https://doi.org/10.1111/j.1365-246X.1975.tb00631.x.

Foulger G.R., 2010. Plates vs. Plumes: A Geological Controversy. Wiley-Blackwell, New York, 328 p.

Fournier M., Jolivet L., Davy P., Thomas J.-C., 2004. Backarc extension and collision: an experimental approach to the tectonics of Asia. Geophysical Journal International 157 (2), 871-889. https://doi.org/10.1111/j.1365-246X.2004. 02223.x.

Gao S., Davis P.M., Liu H., Slack P.D., Zorin Yu.A., Logatchev N.A., Kogan M., Burkholder P.D., Meyer R.P., 1994a. Asymmetric upwarp of the asthenosphere beneath the Baikal rift zone, Siberia. Journal of Geophysical Research: Solid Earth 99 (B8), 15319-15330. https://doi.org/10.1029/94JB00808.

Gao S., Davis P.M., Liu H., Slack P.D., Zorin Yu.A., Mordvinova V.V., Kozhevnikov V.M., Meyer R.P., 1994b. Seismic anisotropy and mantle flow beneath the Baikal rift zone. Nature 371 (6493), 82-84. https://doi.org/10.1038/371149a0. 
Gatinsky Y.G., Rundquist D.V., 2004. Geodynamics of Eurasia: Plate tectonics and block tectonics. Geotectonics 38 (1), 1-16.

Gorbatov A., Widiyantoro S., Fukao Y., Gordeev E., 2000. Signature of remnant slabs in the North Pacific from P-wave tomography. Geophysical Journal International 142 (1), 27-36. https://doi.org/10.1046/j.1365-246x.2000. 00122.x.

Gudmundsson Ó., Sambridge M., 1998. A regionalized upper mantle (RUM) seismic model. Journal of Geophysical Research: Solid Earth 103 (B4), 7121-7136. https://doi.org/10.1029/97JB02488.

Halim N., Cogne J.-P., Chen Y., Atasiei R., Courtillot V., Gilder S., Marcoux J., Zhao R., 1998. New Cretaceous and Early Tertiary paleomagnetic results from Xining-Lanzhou basin, Kunlun and Quigtang blocks, China: implications on the geodynamic evolution of Asia. Journal of Geophysical Research: Solid Earth 103 (B9), 21025-21045. https://doi. org/10.1029/98JB01118.

Han J., Zhou J-B., Wang B., Cao J-L., 2015. The final collision of the CAOB: Constraint from the zircon U-Pb dating of the Linxi Formation, Inner Mongolia. Geoscience Frontiers 6 (2), 211-225. https://doi.org/10.1016/j.gsf.2014.06.003.

He J., Liu M., Li Y., 2003. Is the Shanxi rift of northern China extending? Geophysical Research Letters 30 (23), 2313. https://doi.org/10.1029/2003GL018764.

Hirschmann M.M., Tenner T., Aubaud C., Withers A.C., 2009. Dehydration melting of nominally anhydrous mantle: The primacy of partitioning. Physics of the Earth and Planetary Interiors 176 (1-2), 54-68. https://doi.org/10.1016/ j.pepi.2009.04.001.

Hofmann A.W., 1997. Mantle geochemistry: the message from oceanic volcanism. Nature 385 (6613), 219-229. https://doi.org/10.1038/385219a0.

Hooft E., Toomey D., Solomon S., 2003. Anomalously thin transition zone beneath the Galápagos hotspot. Earth and Planetary Science Letters 216 (1-2), 55-64. https://doi.org/10.1016/S0012-821X(03)00517-X.

Hoshi H., Takahashi M., 1999. Miocene counterclockwise rotation of Northeast Japan: a review and new model. Bulletin of the Geological Survey of Japan 50 (1), 3-16.

Houser C., Masters G., Flanagan M., Shearer P., 2008. Determination and analysis of long-wavelength transition zone structure using SS precursors. Geophysical Journal International 174 (1), 178-194. https://doi.org/10.1111/ j.1365-246X.2008.03719.x.

Huang J., Zhao D., 2006. High-resolution mantle tomography of China and surrounding regions. Journal of Geophysical Research: Solid Earth 111 (B9), B09305. https://doi.org/10.1029/2005JB004066.

Ito E., Takahashi E., 1989. Postspinel transformations in the system $\mathrm{Mg}_{2} \mathrm{SiO}_{4}-\mathrm{Fe}_{2} \mathrm{SiO}_{4}$ and some geophysical implications. Journal of Geophysical Research: Solid Earth 94 (B8), 10637-10646. https://doi.org/10.1029/JB094iB08p 10637.

Jenkyns H.C., Forster A., Schouten S., Sinninghe Damsté J.S., 2004. High temperatures in the Late Cretaceous Arctic Ocean. Nature 432 (7019), 888-892. https://doi.org/10.1038/nature03143.

Jin S., Park P.H., Zhu W., 2007. Micro-plate tectonics and kinematics in Northeast Asia inferred from a dense set of GPS observations. Earth and Planetary Science Letters 257 (3-4), 486-496. https://doi.org/10.1016/j.epsl.2007. 03.011 .

Jolivet L., Tamaki K., Fournier M., 1994. Japan Sea opening history and mechanism: A synthesis. Journal of Geophysical Research: Solid Earth 99 (B11), 22237-22259. https://doi.org/10.1029/93JB03463.

Karato S., 2012. On the origin of the asthenosphere. Earth and Planetary Science Letters 321-322, 95-103. https://doi. org/10.1016/j.epsl.2012.01.001.

Kirillova G.L., 1997. Correlation of Cretaceous events in East Asia with global events. Tikhookeanskaya geologiya (Russian Journal of Pacific Geology) 16 (6), 3-20. (in Russian) [Кириллова Г.Л. Корреляция меловых событий на востоке Азии с глобальными событиями // Тихоокеанская геология. 1997. Т. 16. № 6. С. 3-20].

Kirillova G.L., 2000. The Cretaceous in East of Russia: Sedimentation, Geodynamics, Biodiversity, and Climate. Dal'nauka, Vladivostok, 94 p. (in Russian) [Кириллова Г.Л. Мел востока России: седиментация, геодинамика, биоразнообразие, климат. Владивосток: Дальнаука, 2000. 94 с.].

Kotlyar I.N., Rusakova T.B., 2004. Cretaceous Magmatism and Ore-Bearing Capacity of the Okhotsk-Chukotka Region: Geological-Geochronological Correlation. NEISRI FEB RAS, Magadan, 152 p. (in Russian) [Котляр И.Н., Русакова T.B. Меловой магматизм и рудоносность Охотско-Чукотского региона: геолого-геохронологические корреляции. Магадан: СВКНИИ ДВО РАН, 2004. 152 с.].

Kovalenko D.V., 2010. Paleomagnetism of Late Paleozoic, Mesozoic, and Cenozoic rocks in Mongolia. Russian Geology and Geophysics 51 (4), 387-403. https://doi.org/10.1016/j.rgg.2010.03.006.

Kovalenko V.I., Yarmolyuk V.V., Kovach V.P., Kotov A.B., Kozakov I.K., Sal'nikova E.B., 1996. Sources of Phanerozoic granitoids in Central Asia: Sm-Nd isotope data. Geochemistry International 34 (8), 628-640.

Kozakov I.K., Sal'nikova E.B., Wang T., Didenko A.N., Plotkina Y.V., Podkovyrov V.N., 2007. Crystalline complex in of the Lower Precambrian of the Dzabkhan microcontinent, Central Asia. Stratigraphy and Geological Correlation 15 (2), 121-140. https://doi.org/10.1134/S0869593807020013.

Kozhevnikov V.M., Seredkina A.I., Solovei O.A., 2014. 3D mantle structure of Central Asia from Rayleigh wave group velocity dispersion. Russian Geology and Geophysics 55 (10), 1239-1247. https://doi.org/10.1016/j.rgg.2014.09.010. 
Kravchinsky V.A., Cogné J.-P., Harbert W.P., Kuzmin M.I., 2002. Evolution of the Mongol-Okhotsk ocean as constrained by new palaeomagnetic data from the Mongol-Okhotsk suture zone, Siberia. Geophysical Journal International 148 (1), 34-57. https://doi.org/10.1046/j.1365-246x.2002.01557.x.

Kreemer C., Holt W.E., Haines A.J., 2003. An integrated global model of present-day plate motions and plate boundary deformation. Geophysical Journal International 154 (1), 8-34. https://doi.org/10.1046/j.1365-246X.2003.01917.x.

Larson R.L., 1991a. Latest pulse of Earth: Evidence for a mid-Cretaceous Superplume. Geology 19 (6), 547-550, https://doi.org/10.1130/0091-7613(1991)019<0547:LPOEEF>2.3.CO;2.

Larson R.L., 1991b. Geological consequences of superplumes. Geology 19 (10), 963-966, https://doi.org/10.1130/ 0091-7613(1991)019<0963:GCOS>2.3.CO;2.

Larson R.L., Erba E., 1999. Onset of the mid-Cretaceous greenhouse in the Barremian-Aptian: Igneous events and the biological, sedimentary, and geochemical responses. Paleoceanography 14 (6), 663-678, https://doi.org/10.1029/ 1999PA900040.

Lebedev S., Meier T., van der Hilst R.D., 2006. Asthenospheric flow and origin of volcanism in the Baikal area. Earth and Planetary Science Letters 249 (3-4), 415-424. http://dx.doi.org/10.1016/j.epsl.2006.07.007.

Lei J., Zhao D., 2005. P-wave tomography and origin of the Changbai intraplate volcano in Northeast Asia. Tectonophysics 397 (3-4), 281-295. https://doi.org/10.1016/j.tecto.2004.12.009.

Li C., van der Hilst R., Nafi T.M., 2006. Constraining P-wave velocity variations in the upper mantle beneath Southeast Asia. Physics of the Earth and Planetary Interiors 154 (2), 180-195 https://doi.org/10.1016/j.pepi.2005.09.008.

Li X., Kind R., Priestly K., Sobolev S.V., Tilmann F., Yuan X., Weber M., 2000. Mapping the Hawaiian plume conduit with converted seismic waves. Nature 405 (6789), 938-941. https://doi.org/10.1038/35016054.

Li X., Kind R., Yuan X., Sobolev S.V., Hanks W., Ramesh D.S., Gu Y., Dziewonski A., 2003. Seismic observation of narrow plumes in the oceanic upper mantle. Geophysical Research Letters 30 (6), 1334. https://doi.org/10.1029/ 2002GL015411.

Li Z.W., Roecker S., Li Z.H., Wei B., Wang H., Schelochkov G., Bragin V., 2009. Tomographic image of the crust and upper mantle beneath the western Tien Shan from the MANAS broadband deployment: Possible evidence for lithospheric delamination. Tectonophysics 477 (1-2), 49-57. https://doi.org/10.1016/j.tecto.2009.05.007.

Lithgow-Bertelloni C., Richards M.A., 1998. The dynamics of Cenozoic and Mesozoic plate motions. Reviews of Geophysics 36 (1), 27-78. https://doi.org/10.1029/97RG02282.

Logachev N.A., 1977. Volcanogenic and Sedimentary Formations of the East African Rift Zones. Nauka, Moscow, 183 p. (in Russian) [Логачев Н.A. Вулканогенные и осадочные формации рифтовых зон Восточной Африки. М.: Наука, 1977. 183 с.].

Machetel P., Humler E., 2003. High mantle temperature during Cretaceous avalanche. Earth and Planetary Science Letters 208 (3-4), 125-133. https://doi.org/10.1016/S0012-821X(03)00041-4.

Maruyama S., Santosh M., Zhao D., 2007. Superplume, supercontinent, and postperovskite: Mantle dynamics and antiplate tectonics on the core-mantle boundary. Gondwana Research 11 (1-2), 7-37. https://doi.org/10.1016/j.gr. 2006.06.003.

McArthur J.M., Howarth R.J., Bailey T.R., 2001. Strontium isotope stratigraphy: LOWESS version 3: best fit to the marine Sr-isotope curve for 0-509 Ma and accompanying look-up table for deriving numerical age. Journal of Geology 109 (2), 155-170. https://doi.org/10.1086/319243.

McArthur J.M., Howarth R.J., Shields G.A., 2012. Chapter 7 - Strontium isotope stratigraphy. In: F.M. Gradstein, J.G. Ogg, M.D. Schmitz, G.M. Ogg (Eds.), The geologic time scale. Elsevier, Amsterdam, p. 127-144. https://doi.org/10. 1016/B978-0-444-59425-9.00007-X.

Mechie J., Kind R., Saul J., 2010. The seismological structure of the Tibetan Plateau crust and mantle down to $700 \mathrm{~km}$ depth. In: R. Gloaguen, L. Ratschbacher (Eds.), Growth and collapse of the Tibetan Plateau. Geological Society, London, Special Publication, vol. 353, p. 109-125. https://doi.org/10.1144/SP353.7.

Milanovsky E.E., 1976. Continental Rift Zones. Nedra, Moscow, 279 p. (in Russian) [Милановский Е.Е. Рифтовые зоны континентов. М.: Недра, 1976. 279 с.].

Minister J.B., Jordan T.H., 1978. Present-day plate motions. Journal of Geophysical Research: Solid Earth 83 (11), 5331-5354. https://doi.org/10.1029/JB083iB11p05331.

Mitrovica J., Mound J., Pysklywec R., Milne G., 2000. Sea-level change on a dynamic Earth. In: E. Boschi, G. Ekström, A. Morelli (Eds.), Problems in geophysics for the new millennium. Editrice Compositori, p. 499-529.

Molnar P., 2005. Mio-Pliocene growth of the Tibetan Plateau and evolution of East Asian climate. Paleontologia Electronica 8 (1), $2 \mathrm{~A}$.

Molnar P., Tapponnier P., 1975. Cenozoic tectonics of Asia: consequences and implications of a continental collision. Science 189 (4201), 419-426. https://doi.org/10.1126/science.189.4201.419.

Montelli R., Nolet G., Dahlen F.A., Masters G., Engdahl E.R., Hung S.H., 2004. Finite-frequency tomography reveals a variety of plumes in the mantle. Science 303 (5656), 338-343. https://doi.org/10.1126/science.1092485.

Mordvinova V.V., Deschamps A., Dugarmaa T., Déverchère J., Ulziibat M., Sankov V.A., Artem'ev A.A., Perrot J., 2007. Velocity structure of the lithosphere on the 2003 Mongolian-Baikal transect from SV waves. Izvestiya, Physics of the Solid Earth 43(2), 119-129, https://doi.org/10.1134/S1069351307020036. 
Morgan W., 1971. Convection plumes in the lower mantle. Nature 230 (5288), 42-43. https://doi.org/10.1038/ 230042a0.

Müller R.D., Sdrolias M., Gaina C., Roest W.R., 2008. Age, spreading rates, and spreading asymmetry of the world's ocean crust. Geochemistry, Geophysics, Geosystems 9 (4), Q04006. https://doi.org/10.1029/2007GC001743.

Niu Y., Liu Y., Xue Q., Shao F., Chen S., Duan M., Guo P., Gong H., Hu Y., Hu Z., Kong J., Li J., Liu J., Sun P., Sun W., Ye L., Xiao Y., Zhang Y., 2015. Exotic origin of the Chinese continental shelf: new insights into the tectonic evolution of the western Pacific and eastern China since the Mesozoic. Science Bulletin 60 (18), 1598-1616. https://doi.org/10.1007/ s11434-015-0891-z.

Niu Y., O'Hara M.J., Pearce J.A., 2003. Initiation of subduction zones as a consequence of lateral compositional buoyancy contrast within the lithosphere: a petrological perspective. Journal of Petrology 44 (5), 851-866. https://doi.org/ 10.1093/petrology/44.5.851.

Otofuji Y-I., 1996. Large tectonic movement of the Japan Arc in Late Cenozoic times inferred from paleomagnetism: review and synthesis. The Island Arc 5 (3), 229-249. https://doi.org/10.1111/j.1440-1738.1996.tb00029.x.

Otofuji Y-I., Matsuda T., Itaya T., Shibata T., Matsumoto M., Yamamoto T., Morimoto C., Kulinich R.G., Zimin P.S., Matunin A.P., Sakhno V.G., Kimura K., 2003. Late Cretaceous to early Paleogene paleomagnetic results from Sikhote Alin, Far Eastern Russia: implications for deformation of East Asia. Earth and Planetary Science Letters 130 (1-4), 95-108. https://doi.org/10.1016/0012-821X(94)00254-V.

Owens T., Nyblade A., Gurrola H., Langston C., 2000. Mantle transition zone structure beneath Tanzania, East Africa. Geophysical Research Letters 27 (6), 827-830. https://doi.org/10.1029/1999GL005429.

Parfenov L.M., Berzin N.A., Khanchuk A.I., Badarch G., Belichenko V.G., Bulgatov A.N., Dril S.I., Kirillova G.L., Kuzmin M.I., Nokleberg W.J., Prokopyev A.V., Timofeev V.F., Tomurtogoo O., Yang H., 2003. A model for formation of orogenic belts in Central and Northeast Asia. Tikhookeanskaya geologiya (Russian Journal of Pacific Geology) 22 (6), 7-41 (in Russian) [Парфенов Л.М., Берзин Н.А., Ханчук А.И., Бадарч Г., Беличенко В.Г., Булгатов А.Н., Дриль С.И., Кириллова Г.Л., Кузьмин М.И., Ноклеберг У., Прокопьев А.В., Тимофеев В.Ф., Томуртогоо О., Янь Х. Модель формирования орогенных поясов Центральной и Северо-Восточной Азии // Тихоокеанская геология. 2003. T. 22. № 6. C. 7-41].

Plate-Tectonic map of the Circum-Pacific region, 1984. Pacific basin sheet. Geological Survey, Tusla.

Qin H.F., Li Y.F., Huang S., Cai S.H., Ren S.M., 2013. Palaeomagnetic investigation of Permain sandstone in Taohaiyingzi area of Inner Mongolia and its tectonic significance. Geological Bulletin of China 32 (2-3), 388-398.

Rasskasov S.V., Chebykin E.P., Chuvashova I.S., Stepanova O.N., Vodneva E.N., 2014. Modern mantle activity in Central Asia inferred from U-Th-isotope systematics of Quaternary volcanic rocks: control of mantle melting by growing and thawing glaciers. Izvestiya Irkutskogo Gosudarstvennogo Universiteta. Seriya Nauki o Zemle 8, 91-101 (in Russian) [Рассказов С.В., Чебыкин Е.П., Чувашова И.С., Степанова О.Н., Воднева Е.Н. Современная активность мантии Центральной Азии по U-Th-изотопной систематике вулканических пород в ретроспективе 400 тыс. лет: контроль плавления мантии накоплением и стаиванием ледников // Известия Иркутского госуниверситета. Серия Науки о Земле. 2014. Т. 8. С. 91-101].

Rasskazov S.V., Chuvashova I.S., 2016. The latest geodynamics in Asia: Synthesis of data on volcanic evolution, lithosphere motion, and mantle velocities in the Baikal-Mongolian region. Geoscience Frontiers (in press). https:// doi.org/10.1016/j.gsf.2016.06.009.

Rasskazov S.V., Logachev N.A., Kozhevnikov V.M., Yanovskaya T.B., 2003. Multistage dynamics of the upper mantle in Eastern Asia: relationships between wandering volcanism and low-velocity anomalies. Doklady Earth Sciences 390 (4), 492-496.

Rasskazov S.V., Logatchev N.A., Ivanov A.V., 1998. Correlation of Late Cenozoic tectono-magmatic events between the Baikal rift system and the Southeastern Eurasian plate. Geotectonics 32 (4), 272-285.

Rothacher M., Springer T.A., Schaer S., Beutler G., Brockmann E., 1996. Annual report 1966 of the CODE Analysis Center of the IGS, International GPS service for geodynamics 1996 annual report. California Institute of Technology, Pasadena, USA, p. 201-219.

Ruzhentsev S.V., Pospelov I.I., Badarch G., 1989. Tectonics of Indosinides in Mongolia. Geotektonika (Geotectonics) (6), 13-27 (in Russian) [Руженцев С.В., Поспелов И.И., Бадарч Г. Тектоника индосинид Монголии // Геотектоника. 1989. № 6. C. 13-27].

Sandwell D.T., Anderson D., Wessel P., 2005. Global tectonic maps. In: G.L. Foulger, J.H. Natland, D.C. Presnall, D.L. Anderson (Eds.), Plates, plumes and paradigms. Geological Society of America Special Papers, vol. 388, p. 1-10. https://doi.org/10.1130/0-8137-2388-4.1.

Sankov V.A., Parfeevets A.V., Lukhnev A.V., Miroshnichenko A.I., Ashurkov S.V., 2011. Late Cenozoic geodynamics and mechanical coupling of crustal and upper mantle deformations in the Mongolia-Siberia mobile area. Geotectonics 45 (5), 378-393. https://doi.org/10.1134/S0016852111050049.

Şengör A.M.C., Burke K., 1978. Relative timing of rifting and volcanism on earth and its tectonic implications. Geophysical Research Letters 5 (6), 419-421. https://doi.org/10.1029/GL005i006p00419.

Şengör A.M., Natal'in B.A., 1996. Paleotectonics of Asia: fragments of a synthesis. In: A. Yin, M. Harrison (Eds.), The tectonic evolution of Asia. Cambridge University Press, Cambridge, p.486-641. 
Sengör A.M.C., Natal'in B.A., 2001. Rifts of the world. In: R.E. Ernst, K.L. Buchan (Eds.), Mantle plumes: their identification through time. Geological Society of America Special Papers, vol. 352, p. 389-482. https://doi.org/10.1130/ 0-8137-2352-3.389.

Shen Y., Solomon S., Bjarnason I., Wolfe C., 1998. Seismic evidence for a lower-mantle origin of the Iceland plume. Nature 395 (6697), 62-65. https://doi.org/10.1038/25714.

Simkin T., Tilling R.I., Taggart J.N., Jones W.J., Spall H., 1989. This dynamic planet: world map of volcanoes, earthquakes, and plate tectonics. Smithsonian Institution, US Geological Survey.

Smith A.D., Lewis C., 2003. The planet beyond the plume hypothesis. Earth-Science Reviews 48 (3), 135-182. https://doi.org/10.1016/S0012-8252(99)00049-5.

Stern R.J., 2004. Subduction initiation: spontaneous and induced. Earth and Planetary Science Letters 226 (3-4) 275-292. https://doi.org/10.1016/j.epsl.2004.08.007.

Tapponnier P., Peltzer G., Le Dain A.Y., Armijo R., 1982. Propagating extrusion tectonics in Asia: new insights from simple experiments with plasticine. Geology 10 (12), 611-616. https://doi.org/10.1130/0091-7613(1982)10<611: PETIAN $>2.0 . \mathrm{CO} ; 2$.

Tarduno J., Bunge H.P., Sleep N., Hansen U., 2009. The bent Hawaiian-Emperor hotspot track: Inheriting the mantle wind. Science 324 (5923), 50-53. https://doi.org/10.1126/science.1161256.

Tatsumi Y., Shinjoe H., Ishizuka H., Sager W.W., Klaus A., 1998. Geochemical evidence for a Mid-Cretaceous superplume. Geology 26 (2), 151-154. https://doi.org/10.1130/0091-7613(1998)026<0151:GEFAMC>2.3.C0;2.

Trabucho Alexandre J., Tuenter E., Henstra G.A., van der Zwan K.J., van de Wal R.S.W., Dijkstra H.A., de Boer P.L., 2010. The mid-Cretaceous North Atlantic nutrient trap: Black shales and OAEs. Paleoceanography 25 (4), PA4201. https://doi.org/10.1029/2010PA001925.

Tseden T., Murao S., Dorjgotov D., 1992. Introduction to geology of Mongolia. Bulletin of the Geological Survey of Japan 43 (12), 735-744.

Turcotte D.L., Emerman S.H., 1983. Mechanisms of active and passive rifting. Tectonophysics 94 (1-4), 39-50. https:// doi.org/10.1016/0040-1951(83)90008-2.

Turcotte D.L., Schubert G., 2014. Geodynamics. Third edition. Cambridge University Press, Cambridge, 423 p.

Wan T., 2010. The Tectonics of China. Springer, Berlin, 501 p.

Wei W., Xu J., Zhao D., Shi Y., 2012. East Asia mantle tomography: New insight into plate subduction and intraplate volcanism. Journal of Asian Earth Sciences 60, 88-103. https://doi.org/10.1016/j.jseaes.2012.08.001.

Windley B.F., Alexeiev D., Xiao W., Kröner A., Badarch G., 2007. Tectonic models for accretion of the Central Asian Orogenic Belt. Journal of the Geological Society 164 (1), 31-47. https://doi.org/10.1144/0016-76492006-022.

Wuming B., Vingy C., Ricard Y., Froidevaux C., 1992. On the origin of deviatoric stress in the lithosphere. Journal of Geophysical Research: Solid Earth 97 (B8), 11729-11737. https://doi.org/10.1029/91JB00292.

Xи X., Ma X., 1992. Geodynamics of the Shanxi Rift system, China. Tectonophysics 208 (1-3), 325-340. https://doi.org/ 10.1016/0040-1951(92)90353-8.

Xu Y.G., Huang X.L., Ma J.L., Wang Y.B., Iizuka Y., Xu J.F., Wang Q., Wu X.Y., 2004. Crust-mantle interaction during the tectono-thermal reactivation of the North China Craton: constraints from SHRIMP zircon U-Pb chronology and geochemistry of Mesozoic plutons from western Shandong. Contributions to Mineralogy and Petrology 147 (6), 750-767. https://doi.org/10.1007/s00410-004-0594-y.

Yanovskaya T.B., Kozhevnikov V.M., 2003. 3D S-wave velocity pattern in the upper mantle beneath the continent of Asia from Rayleigh wave data. Physics of the Earth and Planetary Interiors 138 (3-4), 263-278. https://doi.org/ 10.1016/S0031-9201(03)00154-7.

Yanshin A.L. (Ed.), 1974. Tectonics of the Mongolian People's Republic. Nauka, Moscow, 283 p. (in Russian) [Тектоника Монгольской Народной Республики / Ред. А.Л. Яншин. М.: Наука, 1974. 283 с.]

Yarmolyuk V.V., Kudryashova E.A., Kozlovsky A.M., Savatenkov V.M., 2007. Late Cretaceous - Early Cenozoic volcanism of Southern Mongolia: A trace of the South Khangai mantle hot spot. Journal of Volcanology and Seismology 1 (1), 1-27. https://doi.org/10.1134/S0742046307010010.

Yoshioka S., Sanshadokoro H., 2002. Numerical simulations of deformation and dynamics of horizontally lying slab. Geophysical Journal International 151 (1), 69-82. https://doi.org/10.1046/j.1365-246X.2002.01735.x.

Zhang Y-S., Tanimoto T., 1992. Riges, hotspots and their interaction as observed in seismic velocity maps. Nature 355 (6355), 45-49. https://doi.org/10.1038/355045a0.

Zhao D., 2009. Multiscale seismic tomography and mantle dynamics. Gondwana Research 15 (3-4), 297-323. https:// doi.org/10.1016/j.gr.2008.07.003.

Zhao D., Lei J., Inoue T., Yamada A., Gao S.S., 2006. Deep structure and origin of the Baikal rift zone. Earth and Planetary Science Letters 243 (3-4), 681-691. https://doi.org/10.1016/j.epsl.2006.01.033.

Zhou J.B., Wilde S.A., 2013. The crustal accretion history and tectonic evolution of the NE China segment of the Central Asian Orogenic Belt. Gondwana Research 23 (4), 1365-1377. https://doi.org/10.1016/j.gr.2012.05.012.

Zorin Y.A., 1971. Recent Structure and Isostasy of the Baikal Rift Zone and Adjacent Areas. Nauka, Moscow, 168 p. (in Russian) [Зорин Ю.А. Новейшая структура и изостазия Байкальской рифтовой зоны и сопредельных территорий. М.: Наука, 1971. 168 с.] 
I.S. Chuvashova et al.: The latest geodynamics in Central Asia...

Zorin Y.A., 1999. Geodynamics of the western part of the Mongolia-Okhotsk collisional belt, Trans-Baikal region (Russia) and Mongolia. Tectonophysics 306 (1), 33-56. https://doi.org/10.1016/S0040-1951(99)00042-6.

Zorin Y.A., Turutanov E.K., Kozhevnikov V.M., Rasskazov S.V., Ivanov A.I., 2006. The nature of Cenozoic upper mantle plumes in East Siberia (Russia) and Central Mongolia. Geologiya i Geofizika (Russian Geology and Geophysics) 47 (10), 1056-1070.

Zorin Y.A., Turutanov E.Kh., Mordvinova V.V., Kozhevnikov V.M., Yanovskaya T.B., Treussov A.V., 2003. The Baikal rift zone: the effect of mantle plumes on older structure. Tectonophysics 371 (1-4), 153-173. https://doi.org/10. 1016/S0040-1951(03)00214-2.

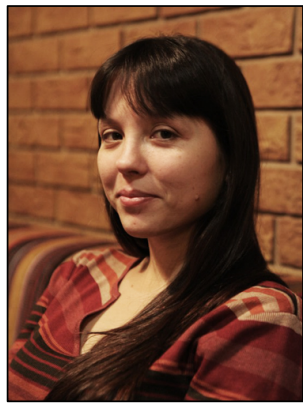

Чувашова Ирина Сергеевна, канд. геол.-мин. наук, с.н.с.

Институт земной коры СО РАН

664033, Иркутск, ул. Лермонтова, 128, Россия

Иркутский государственный университет, геологический факультет 664003, Иркутск, ул. Ленина, 3, Россия

Тел. +7(3952)511659; 凶 e-mail: chuvashova@crust.irk.ru

Chuvashova, Irina S., Candidate of Geology and Mineralogy, Senior Researcher Institute of the Earth's Crust, Siberian Branch of RAS

128 Lermontov street, Irkutsk 664033, Russia

Irkutsk State University, Geological Faculty

3 Lenin street, Irkutsk 664003, Russia

Tel. +7(3952)511659; ه e-mail: chuvashova@crust.irk.ru

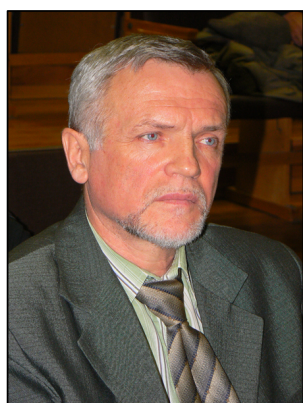

Рассказов Сергей Васильевич, докт. геол.-мин. наук, профессор, зав. лабораторией Институт земной коры СО РАН 664033, Иркутск, ул. Лермонтова, 128, Россия

Иркутский государственный университет, геологический факультет 664003 , Иркутск, ул. Ленина, 3, Россия

Тел. (3952)511659; e-mail: rassk@crust.irk.ru

Rasskazov, Sergei V., Doctor of Geology and Mineralogy, Professor, Head of Laboratory Institute of the Earth's Crust, Siberian Branch of RAS

128 Lermontov street, Irkutsk 664033, Russia

Irkutsk State University, Geological Faculty

3 Lenin street, Irkutsk 664003, Russia

Tel. +7(3952)511659; e-mail: rassk@crust.irk.ru

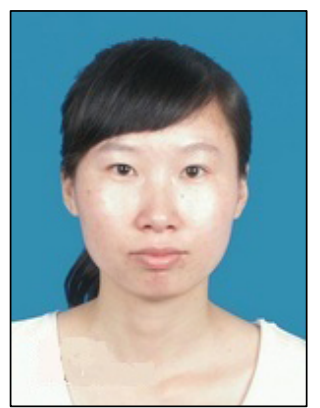

Йи-минь Сунь, научный сотрудник

Институт вулканов и минеральных источников Хэйлунцзянской академии наук

164155, Удаляньчи, Хэйлунцзян, Китай

e-mail: 894817259@qq.com

Yi-min Sun, Research assistant

Institute of Volcano and Mineral Spring, Heilongjiang Academy of Science

Wudalianchi 164155, Heilongjiang, China

e-mail: 894817259@qq.com 